\title{
POKYNY EVROPSKÉ KOMISE K ČL. 17 - KRITICKÉ ÚVAHY K UPLATNĚNÍ V PRAXI ${ }^{1}$
}

\author{
ROSTISLAV SLIWKA ${ }^{2}$
}

\begin{abstract}
ABSTRAKT
Článek se zabývá pokyny Evropské komise k uplatňování čl. 17 směrnice (EU) 2019/790 uvedenými ve Sdělení Komise Evropskému parlamentu a Radě COM(2021) 288 final ze dne 4. 6. 2021. Zkoumá jednotlivé aspekty pokynů a na praktických př́padech se snaži znázornit jejich možné aplikační problémy. Rovněž tak srovnává obsah pokynů s návrhem novely autorského zákona a občanského zákoníku, kterou by měla být výše uvedená směrnice implementováno do českého práva.
\end{abstract}

\section{KLÍČOVÁ SLOVA}

odpovědnost ISP; autorské právo na jednotném digitálním trhu; Evropská Komise; článek 17

\section{ABSTRACT}

This article deals with the Guidelines of European Commission on the application of Article 17 of the Directive 2019/790 presented in the Communication from the Commission to the European Parliament and the Council COM(2021) 288 final from 4th June 2021. It examines individual aspects of Guidelines and it se-

1 Článek byl vypracován jako modulová práce $\mathrm{k}$ předmětu Právo e-commerce v rámci programu LL.M. v právu informačních a komunikačních technologií Masarykovy univerzity.

2 Mgr. Rostislav Sliwka je je absolventem Právnické fakulty Univerzity Karlovy a studentem programu LL.M. v právu informačních a komunikačních technologií Masarykovy univerzity. Aktuálně působí jako právník v OSA - Ochranném svazu autorském pro práva $\mathrm{k}$ dílům hudebním, z.s.. Kontaktní e-mail: rostasliwka@gmail.com 
eks to present its possible aplication problems on practical issues. The article also compares Guidelines with proposals to amend Czech Copyright Act and Civil Code by which the abovementioned Directive shall be implemented into the Crech law.

\section{KEYWORDS}

ISP liability; Copyright on the Digital Single Market; European Commission; Article 17

\section{1. ÚVOD}

V roce 2019 došlo v oblasti autorského práva k obohacení unijního acquis o dvě nové směrnice. Jednou z nich je směrnice 790/2019 o autorském právu na jednotném digitálním trhu. ${ }^{3}$ Tato směrnice obsahuje ve svém článku 17 speciální úpravu odpovědnosti tzv. poskytovatelů služeb sdílení obsahu online za užití autorskoprávně chráněného obsahu nahrávaného uživateli služeb sdílení obsahu online. Debata před přijetím směrnice i po jejím přijetí byla velmi vzrušená, přičemž většina debat se stáčela právě k článku 17. Ve spojitosti s předběžnými otázkami ve spojených věcech C682/18 a C-683/18 ${ }^{4}$ a s ohledem na stížnost Polska k Soudnímu dvoru EU ${ }^{5}$ směřující ke zrušení části článku 17 pro rozpor se základními právy stanovenými Listinou základních práv $\mathrm{EU}^{6}$ se proto pozornost všech zúčastněných stran stočila právě $\mathrm{k}$ vydání pokynů Evropské komise $\mathrm{k}$ uplatňování

3 Směrnice Evropského parlamentu a Rady (EU) 2019/790 ze dne 17. dubna 2019 o autorském právu a právech s ním souvisejících na jednotném digitálním trhu a o změně směrnic 96/9/ES a 2001/29/ES. In: EUR-Lex [právní informační systém]. Úřad pro publikace Evropské unie [cit. 11. 7. 2021]. Dostupné z: https://eurlex.europa.eu/legalcontent/EN-CS/TXT/?uri = CELEX:32019L0790\&from = cs (dále jen „DSM směrnice“).

4 Rozhodnutí Soudního dvora (velkého senátu) ze dne 22. června 2021. Frank Peterson proti Google LLC a další a Elsevier Inc. proti Cyando AG. Spojené věci C-682/18 a C-683/18. Dostupné z: https://curia.europa.eu/juris/document/document.jsf?text $=\&$ docid $=$ 243241\&pageIndex $=0 \&$ doclang $=$ CS\&mode $=1$ st $\&$ dir $=\& o c c=$ first $\&$ part $=1 \& \operatorname{cid}=592163$ (dále jen „rozhodnutí ve věci YouTube/Uploaded“).

5 Žaloba podaná dne 24. května 2019. Polská republika proti Evropskému parlamentu a Radě Evropské unie. Věc C-401/19. Dostupné z: https://curia.europa.eu/juris/document/document.jsf?

text $=\&$ docid $=216823 \&$ pageIndex $=0 \&$ doclang $=$ CS\&mode $=$ req\&dir $=\&$ occ $=$ first\&part $=$ $1 \&$ cid = 592943 (dále jen „polská žaloba“). 
čl. 17 DSM směrnice v návaznosti na mandát daný Evropské Komisi v čl. 17 odst. 10 směrnice. Komise však tyto pokyny vydala až dne 4. 6. 2021, tj. tři dny před implementační lhůtou DSM směrnice dle jejího článku 29. ${ }^{7}$

Z toho vyplývá, že většina států již obsah těchto pokynů jen obtížně promítne do svých návrhů na provedení DSM směrnice do vnitrostátního práva, a to bud' z toho důvodu, že novou úpravu již s ohledem na implementační lhůtu přijaly, nebo z důvodu již probíhajícího legislativního procesu, který ne vždy bude umožňovat razantní změny návrhů. ${ }^{8}$ Tato skutečnost je o to negativnější $v$ tom směru, že Pokyny výslovně mluví v konkrétních případech o tom, že členské státy mají čl. 17 DSM směrnice provést konkrétním způsobem. V tomto kontextu je proto vhodné uvést, že český návrh novely autorského zákona ${ }^{9}$ a občanského zákoníku ${ }^{10}$ je v době psaní tohoto článku již zařazen na pořad jednání Poslanecké sněmovny ČR jako sněmovní tisk $1246,{ }^{11}$ přičemž je zjevné, že je více shodný s textem samotné DSM směrnice a s Pokyny se ne vždy shoduje, jak bude uvedeno dále.

6 Listina základních práv Evropské unie. In: EUR-Lex [právní informační systém]. Úřad pro publikace Evropské unie [cit. 11. 7. 2021]. Dostupné z: https://eur-lex.europa.eu/legalcontent/CS/ALL/?uri = CELEX:12012P/TXT (dále jen „LZPEU“).

7 Sdělení Komise Evropskému parlamentu a Radě $\operatorname{COM(2021)~} 288$ final ze dne 4. 6. 2021. Pokyny k článku 17 směrnice 2019/790 o autorském právu na jednotném digitálním trhu. Dostupné z: In: EUR-Lex [právní informační systém]. Úřad pro publikace Evropské unie [cit. 11. 7. 2021]. Dostupné z: https://eur-lex.europa.eu/legal-content/CS/TXT/HTML/? uri $=$ CELEX:52021DC0288\&from = EN (dále jen „Pokyny“).

8 K přehledu implementačních prací v členských státech EU viz Copyright in the Digital Single Market Directive - Implementation. An EU Copyright Reform Resource. create.ac.uk [online]. CREATe [cit. 11. 7. 2021]. Dostupné z: https://www.create.ac.uk/cdsm-implementation-resource-page/.

9 Zákon č. 121/2000 Sb., o právu autorském, o právech souvisejících s právem autorským a o změně některých zákonů, ve znění pozdějších předpisů. In: ASPI [online právní informační systém]. Wolters Kluwer [cit. 11. 7. 2021]. Dostupné z: https://www.aspi.cz/products/lawText/1/49278/1/2 (dále jen „AZ“).

10 Zákon č. 89/2012 Sb. , občanský zákoník, ve znění pozdějších předpisů. In: ASPI [online právní informační systém]. Wolters Kluwer [cit. 11. 7. 2021]. Dostupné z: https://www.aspi.cz/products/lawText/1/74907/1/2 (dále jen „OZ“).

11 Sněmovní tisk 1246, Novela z. - autorský zákon - EU. psp.cz [online]. Poslanecká sněmovna Parlamentu ČR [cit. 11. 7. 2021]. Dostupné z: https://www.psp.cz/sqw/historie.sqw? $\mathrm{o}=8 \& \mathrm{t}=1246$ (dále jen „návrh novely AZ a OZ“). 
$\mathrm{Na}$ veřejnosti se proto již objevují vůči Pokynům kritické hlasy, a to nejen kvůli jejich pozdnímu vydání, ale též kvůli jejich občasné nejednoznačnosti a obsahu, který v mnoha bodech překračuje povinnosti stanovené samotnou DSM směrnicí. Tyto hlasy se objevují na straně nositelů práv, ${ }^{12}$ neziskových sdružení na ochranu práv na internetu ${ }^{13}$ i na straně akademiků. ${ }^{14}$

V tomto článku si proto kladu za cíl kriticky zhodnotit obsah Pokynů, a to především s ohledem na možné uplatnění Pokynů v licenční praxi a s ohledem na již zveřejněný návrh novely $\mathrm{AZ}$ a $\mathrm{OZ}$. Záměrem je dále určit, v kterých oblastech již Komise dle mého názoru překračuje obsah samotné DSM směrnice a kde stanovuje požadavky, které budou v praxi jen stěží realizovatelné.

\section{POKYNY KOMISE}

\subsection{MANDÁT KOMISE K VYDÁNÍ POKYNŮ}

Komise EU byla oprávněna k vydání Pokynů na základě čl. 17 odst. 10 DSM směrnice. Toto ustanovení především uvádí, že Komise vydá na základě dialogu se zúčastněnými stranami pokyny „pro uplatňování tohoto článku, zejména pokud jde o spolupráci uvedenou v odstavci 4. “ Z toho vyplývá, že Komise se měla primárně zaměřit na aspekty licencování chráněného obsahu v režimu čl. 17, na tzv. staydown a notice-and-takedown procedury a na praktické uplatňování uživatelských záruk pro oprávněná užití chráněného obsahu.

${ }^{12}$ Viz např. tisková zpráva sdružení kolektivních správců GESAC - GESAC reacts to Article 17 Guidelines. authorsocieties.eu [online]. GESAC [cit. 11. 7. 2021]. Dostupné z: https:// authorsocieties.eu/gesac-reacts-to-article-17-guidelines/.

13 The EU Commission's Refuses to Let Go of Filters. eff.org [online]. EFF [cit. 11. 7. 2021]. Dostupné z: https://www.eff.org/deeplinks/2021/06/eu-commissions-guidance-article-17did-not-let-go-filters.

14 JÜTTE, Bernd Justin, PRIORA, Giulia. A further step into a systematic distortion: The EC Guidance on Article 17 CDSM Directive further complicates copyright exceptions. coyprightblog.kluweriplaw.com [online]. Wolters Kluwer [cit. 11. 7. 2021]. Dostupné z: http:// copyrightblog.kluweriplaw.com/2021/06/09/a-further-step-into-a-systematic-distortionthe-ec-guidance-on-article-17-cdsm-directive-further-complicates-copyright-exceptions/. 
Domnívám se tudíž, že Komise po věcné stránce částečně překročila svůj mandát, pokud v bodě III. Pokynů popisuje, na koho by se měl režim čl. 17 DSM směrnice vztahovat, tj. blíže popisuje jednotlivá kritéria tzv. poskytovatelů služeb sdílení obsahu online ${ }^{15}$ dle čl. 2 bod 6 DSM směrnice.

Ačkoliv lze chápat snahu Komise vnést do dané oblasti právní jistotu a ačkoliv byla právě otázka osobní působnosti čl. 17 DSM směrnice ožehavým tématem, Komisi toto posouzení nepřísluší a bude až na vnitrostátních soudech a následně pak i na Soudním dvoru EU, aby svým výkladem blíže vykreslil rozsah osobní působnosti. ${ }^{16}$

\subsection{PRÁVNÍ POVAHA POKYNŮ}

Sdělení Komise nemá obecně dle evropského práva právní závaznost. Slouží tedy pouze jako určitý návod či pomůcka k výkladu práva či praktické aplikaci unijních předpisů a lze jej chápat jako tzv. soft law. Z toho vyplývá, že Soudní dvůr EU nebude při výkladu ustanovení DSM směrnice těmito Pokyny vázán, nebot pouze on je oprávněn podávat v souladu s čl. 267 Smlouvy o fungování EU ${ }^{17}$ závazný výklad právních předpisů Unie. Lze si nicméně představit, že Soudní dvůr EU tyto Pokyny může vzít jako východisko pro své úvahy, jako tomu již učinil i u jiných dokumentů z kategorie soft law. ${ }^{18}$

Pokyny tak slouží spíše pro zákonodárce, popř. mohou posloužit jako podpůrný dokument pro vnitrostátní soudy v členských státech. Nicméně Pokyny nijak nestanovují práva a povinnosti jednotlivců a tedy se na ně tito nemohou před vnitrostátními soudy spolehnout. Lze tak očekávat, že někte-

15 Dále jen „PSSOO“.

16 Bližší výklad obsahu Pokynů stran definice PSSOO je proveden v kapitole 2.3.2.

17 Smlouva o fungování Evropské unie. In: EUR-Lex [právní informační systém]. Úřad pro publikace Evropské unie [cit. 11. 7. 2021]. Dostupné z: https://eur-lex.europa.eu/legalcontent/CS/TXT/?uri $=$ celex\%3A12012E\%2FTXT.

18 Soudní dvůr EU takto respektuje např. průvodce Bernskou úmluvou, jakožto výkladový dokument vypracovaný organizací WIPO v r. 1978, viz bod 41 odůvodnění rozhodnutí Soudního dvora (třetího senátu) ze dne 7. prosince 2006. SGAE proti Rafael Hoteles SA. Věc C-306/05. Dostupné z: https://curia.europa.eu/juris/document/document.jsf? text $=$ \&docid $=66355 \&$ pageIndex $=0 \&$ doclang $=\mathrm{CS} \&$ mode $=1$ st $\&$ dir $=\&$ occ $=$ first $\&$ part $=1 \&$ cid $=1214666$. 
ré soudy i s odkazem na Pokyny budou žádat Soudní dvůr EU o závazný výklad DSM směrnice. ${ }^{19}$ Rovněž tak lze očekávat, že výklad Pokynů se bude průběžně měnit, jak v Pokynech uznává sama Komise s odkazem na polskou žalobu směřující ke zrušení části čl. 17 DSM směrnice. ${ }^{20}$

Tím spíše dospívám k závěru, že implementace DSM směrnice by se měla co nejvíce držet textu směrnice a uplatnění Pokynů, at už v legislativních pracích či před vnitrostátními soudy, by mělo být spíše rezervované a vést $\mathrm{k}$ pokládání předběžných otázek k Soudnímu dvoru EU.

\subsection{OBSAH POKYNU゚}

\subsection{1 ČLÁNEK 17 DSM SMĚRNICE JAKOŽTO ZVLÁŠTNÍ REŽIM LICENCOVÁNÍ A ODPOVĚDNOSTI V OBLASTI AUTORSKÉHO PRÁVA}

Pokyny shrnují, že DSM směrnice v čl. 17 „stanoví zvláštní režim pro svolení a odpovědnost $v$ oblasti autorského práva a práv souvisejících sautorským právem," a to z toho důvodu, že "podle předchozího právního rámce nebyla odpovědnost [PSSOO] z hlediska autorského práva za úkony jejich uživatelů jasná. “21

$\mathrm{V}$ tomto bodě je na místě uvést, že DSM směrnice uvádí ve svém recitálu 64 následující:

„Je vhodné v této směrnici objasnit, že [PSSOO] vykonají úkon sdě-

lení veřejnosti nebo zpř́stupnění veřejnosti, pokud poskytnou veřejnosti př́stup $k$ dỉium chráněným autorským právem nebo $k$ jiným předmětům ochrany nahrávaným jejich uživateli. “

Český návrh implementace čl. 17 DSM směrnice v tomto směru nijak nevybočuje $\mathrm{z}$ úpravy samotné směrnice a pouze dovozuje $\mathrm{v}$ navrhovaném doplnění odst. $2 \mathrm{v} \S 18 \mathrm{AZ}$, že sdělováním veřejnosti „zpưsobem, že kdokoli může mít $k$ němu př́stup na místě a $v$ čase podle své vlastní volby zejména počítačovou nebo obdobnou sitit“ je též „zpř́stupňování díla veřejnosti poskytovate-

\footnotetext{
19 ROSATI, Eleonora. Commission unveils Article 17 Guidance: 3 highlights. ipkitten.blogspot. com [online]. IPKat [cit. 11. 7. 2021]. Dostupné z: https://ipkitten.blogspot.com/ 2021/06/commission-unveils-article-17-guidance.html.

${ }^{20}$ Pokyny, s. 1.

${ }^{21}$ Pokyny, s. 1.
} 
lem služby pro sdílení obsahu online podle $\S 46$ odst. 1, bylo-li dílo nahráno uživatelem takové služby.“22 Důvodová zpráva pouze uvádí, že se shodně se směrnicí „rýslovně konstatuje, že poskytovatel služby pro sdílení obsahu online provádí úkon sdělování díla veřejnosti, pokud zpř́stupňuje veřejnosti dílo nebo jiný předmět ochrany nahraný uživatelem takové služby.“23

V akademické sfére probíhala debata, zda by ustanovení recitálu 64 DSM směrnice mělo být vykládáno $\mathrm{v}$ tom směru, že se DSM směrnicí pouze potvrzuje skutečnost, že služby, které odpovídají dnešnímu pojmu PSSOO, sdělují díla veřejnosti, pokud zpřístupňují obsah nahrávaný jejich uživateli, už v době před přijetím DSM směrnice - tato debata se následně vede především o povahu práva na sdělování veřejnosti uvedeného v čl. 17 DSM směrnice, $\mathrm{tj}$. zda jde o novou podkategorii práva na sdělování veřejnosti v kontextu mezinárodních úmluv, zda jde o lex specialis $\mathrm{k}$ čl. 3 směrnice $2001 / 29 / \mathrm{ES}^{24}$ nebo zda jde o právo sui generis. ${ }^{25}$

S ohledem na rozhodnutí Soudního dvora EU ve věci YouTube/Uploaded je nicméně již zřejmé, že objasnění uvedené v recitálu 64 DSM směrnice se uplatní až s implementací této nové směrnice. ${ }^{26}$ Soudní dvưr tak uvádí:

22 Viz $§ 18$ odst. 2 návrhu novely AZ a OZ.

${ }^{23}$ Viz s. 34 důvodové zprávy k Návrhu zákona, kterým se mění zákon č. 121/2000 Sb., o právu autorském, o právech souvisejících s právem autorským a o změně některých zákonů (autorský zákon), ve znění pozdějších předpisů, a další související zákony. apps.odok.cz [online]. Elektronická knihovna připravované legislativy pro veřejnost [cit. 14. 7. 2021]. Dostupné z: https://apps.odok.cz/veklep-history-version?pid=KORNBZVFDU6E (dále jen „důvodová zpráva“).

24 Směrnice Evropského parlamentu a Rady 2001/29/ES ze dne 22. května 2001 o harmonizaci určitých aspektů autorského práva a práv s ním souvisejících v informační společnosti. In: EUR-Lex [právní informační systém]. Úřad pro publikace Evropské unie [cit. 11. 7. 2021]. Dostupné z: https://eur-lex.europa.eu/legal-content/CS/TXT/?uri=CELEX:32001L0029 (dále jen „informační směrnice“).

25 HUSOVEC, Martin, QUINTAIS, J. P. How to license Article 17? Exploring the Implementation Options for the New EU Rules on Content-Sharing Platforms. [online] s. 14 an. [cit. 11. 7. 2021]. Dostupné z: https://papers.ssrn.com/sol3/papers.cfm?abstract_id $=3463011$.

${ }^{26}$ I tak nicméně platí, že odůvodnění unijních směrnic a nařízení mají pouze podpůrný charakter a nemají sama o sobě právní závaznost, viz bod 16 odůvodnění rozhodnutí Soudního dvora EU (pátého senátu) ze dne 2. dubna 2009. Hauptzollamt Bremen proti J. E. Tyson Parketthandel GmbH hanse j. Věc C-134/08. Dostupné z: https://curia.europa.eu/juris/document/document.jsf?text $=\&$ docid $=73634 \&$ pageIndex $=0 \&$ doclang $=$ CS\&mode $=1$ st $\&$ dir $=\&$ occ $=$ first $\&$ part $=1 \& \operatorname{cid}=1222119$. 
„[...] čl. 3 odst. 1 směrnice o autorském právu musí být vykládán $v$ tom smyslu, že provozovatel platformy pro sdílení videí nebo platformy pro ukládání a sdílení souborů, na které mohou uživatelé protiprávně zpř̌stupnit veřejnosti chráněné obsahy, neuskutečňuje „sdělování těchto obsahů „verejnosti“ ve smyslu tohoto ustanovení, ledaže by nad rámec pouhého zpř̌stupnění platformy přispíval ke zpř́stupnění takových obsahů veřejnosti v rozporu s autorským právem. “27

Soudní dvưr v daném rozhodnutí však již v úvodu uvedl, že jeho výklady na dané předběžné otázky „se netýkají režimu, který vstoupil v platnost po této době, jenž byl zaveden článkem 17 [DSM směrnice].“28

Pokyny pak dovozují, že právo na sdělování veřejnosti uvedené v čl. 17 DSM směrnice je lex specialis $\mathrm{k}$ čl. 3 informační směrnice a čl. 14 směrnice 2000/31/ES ${ }^{29}$ - nejde však o nové právo v kontextu autorského práva s odkazem na recitály 64 a 65 DSM směrnice, které uvádějí, že čl. 17 nejsou dotčeny pojmy sdělování a zpřístupnění díla veřejnosti již upravené v unijním právo, ani možnost uplatnění čl. 3 informační směrnice na úkony PSSOO nespadající do působnosti čl. 17 DSM směrnice. ${ }^{30}$

Quintais dané komentuje tak, že dle Pokynů právo na sdělování veřejnosti uvedené v čl. 17 DSM směrnice je právem odlišným od práva dle čl. 3 informační směrnice, nicméně nejde o zcela nové právo či právo sui generis. ${ }^{31}$ Nordemann v době před vydáním Pokynů uváděl, že vzájemný vztah mezi čl. 3 informační směrnice a čl. 17 DSM směrnice je třeba posu-

27 Bod 102 odůvodnění rozhodnutí ve věci YouTube/Uploaded.

28 Bod 59 odůvodnění rozhodnutí ve věci YouTube/Uploaded.

${ }^{29}$ Směrnice Evropského parlamentu a Rady 2000/31/ES ze dne 8. června 2000 o některých právních aspektech služeb informační společnosti, zejména elektronického obchodu, na vnitřním trhu (směrnice o elektronickém obchodu). In: EUR-Lex [právní informační systém]. Úřad pro publikace Evropské unie [cit. 11. 7. 2021]. Dostupné z: https://eur-lex.europa.eu/legal-content/CS/ALL/?uri=CELEX\%3A32000L0031 (dále jen „směrnice e-commerce").

30 Pokyny, s. 2.

31 QUINTAIS, Joao Pedro. Commission's Guidance on Art. 17 CDSM Directive: the authorisation dimension. coyprightblog.kluweriplaw.com [online]. Wolters Kluwer [cit. 11. 7. 2021]. Dostupné z: http://copyrightblog.kluweriplaw.com/2021/06/10/commissions-guidanceon-art-17-cdsm-directive-the-authorisation-dimension/. 
zovat na třech úrovních - práv $\mathrm{k}$ užití, právní odpovědnosti a výjimek a omezení. V první úrovní dospíval $\mathrm{k}$ tomu, že právo $\mathrm{v}$ obou směrnicích se nijak neliší a čl. 17 DSM směrnice závisí na aplikaci čl. 3 informační směrnice. $\mathrm{Z}$ toho důvodu by měly členské státy při implementaci využívat stávající úpravu práva na sdělování veřejnosti. ${ }^{32} \mathrm{O}$ povaze těchto práv lze najít množství dalších názorů z akademické obce. ${ }^{33}$

Na tom je dobře vidět určitý chaos, který v posouzení práva uvedeného v čl. 17 DSM směrnice aktuálně vládne. Tím spíše jsem toho názoru, že nebylo úlohou Komise v Pokynech podávat výklad povahy práva na sdělování veřejnosti a tuto otázku měla ponechat na Soudním dvoru EU. Pokyny tak vedou spíše $\mathrm{k}$ větší právní nejistotě adresátů.

Tato otázka má totiž zcela zásadní význam v licenční praxi kolektivních správců. Samotné Pokyny na více místech uznávají nepominutelnou roli kolektivních správců dle směrnice $2014 / 26 / \mathrm{EU}^{34}$ a jejich význam pro fungování režimu dle čl. 17 DSM směrnice. ${ }^{35}$ Pokud bychom dospěli $\mathrm{k}$ tomu, že právo uvedené v čl. 17 DSM směrnice je do určité míry odlišné povahy, mohou být dotčena oprávnění kolektivních správců $\mathrm{k}$ výkonu kolektivní správy a smluvní vztahy s nositeli práv, což může již v počátcích značně ztížit aplikaci režimu dle čl. 17 . V tomto směru lze proto z praktického hlediska ocenit stávající výše uvedenou podobu návrhu novely AZ a OZ, který pro implementaci využívá stávající právo dle $\S 18$ odst. 2 AZ. Domnívám se

32 NORDEMANN, Jan Bernd. Art. 17 DSMCD a Class of Its Own? How to Implement Art. 17 Into the Existing National Copyright Acts - Also a Comment on the Recent German Discussion Draft. [online] s. 13 an. Dostupné z: https://ssrn.com/abstract $=3649626$.

33 Viz ROSATI, Eleonora. The legal nature of Article 17 of the Copyright DSM Directive, the (lack of) freedom of Member States, and why the German implementation proposal is not compatible with EU law. ipkitten.blogspot.com [online]. IPKat [cit. 28. 7. 2021]. Dostupné z: https://ipkitten.blogspot.com/2020/08/the-legal-nature-of-article-17-of.html.

34 Směrnice Evropského parlamentu a Rady 2014/26/EU ze dne 26. února 2014 o kolektivní správě autorského práva a práv s ním souvisejících a udělování licencí pro více území $\mathrm{k}$ právům $\mathrm{k}$ užití hudebních děl online na vnitřním trhu. In: EUR-Lex [právní inormační systém]. Úřad pro publikace Evropské unie [cit. 11. 7. 2021]. Dostupné z: https://eurlex.europa.eu/legal-content/CS/TXT/HTML/?uri = CELEX:32014L0026\&from = EN （dále jen „směrnice o KS“).

35 Viz např. Pokyny, s. 7, 9 ad. 
však, že i z teoretického hlediska je tento závěr jediným správným, což potvrzují recitály 64 a 65 DSM směrnice.

Dle mého názoru je tudíž třeba na právo na sdělování veřejnosti dle čl. 17 DSM směrnice $\mathrm{z}$ autorskoprávního hlediska nahlížet jako na určité vydělení sdělování veřejnosti dle čl. 3 informační směrnice pouze pro účely zavedení specifického režimu odpovědnosti některých uživatelů, kteří užívají chráněný obsah sdělováním veřejnosti dle čl. 3 informační směrnice, a uplatnění výjimek a omezení z autorského práva. $\mathrm{S}$ odkazem na judikaturu Soudního dvora EU a odůvodnění DSM směrnice lze říci, že je pojem sdělování díla veřejnosti v DSM směrnici uveden ve stejném kontextu a sleduje stejné cíle jako $v$ př́ípadě informační směrnice. ${ }^{36}$

Lze tedy souhlasit s Pokyny Komise, že čl. 17 DSM směrnice nezavádí nové právo odlišné od čl. 3 informační směrnice. I tak by nicméně měla být tato otázka vyhrazena Soudnímu dvoru EU a Komise zde dle mého názoru zachází věcně nad rámec toho, co po ní bylo čl. 17 odst. 10 DSM směrnice požadováno.

\subsubsection{POSKYTOVATELÉ SLUŽEB SDÍLENÍ OBSAHU ONLINE - ČL. 2 BOD 6 DSM SMĚRNICE}

Pokyny se definici PSSOO věnují v kontextu celých Pokynů poměrně stručně. Nad rámec textace směrnice ${ }^{37}$ uvádějí především to, že členské státy by měly explicite implementovat i vymezení PSSOO z odůvodnění směrnice. Jde tak zejména o recitály 61, 62 a 63 směrnice, které „poskytují důležitá upřesnění, pokud jde o to, které druhy poskytovatelů služeb jsou v definici zahrnuty nebo jsou z ní vyloučeny." Dle Pokynů se tak definice PSSOO vztahuje především na subjekty, které mají důležité postavení na trhu, kde soutěží s ostatními poskytovateli zejména audiovizuálních služeb, a cílí na

36 Bod 74 odůvodnění rozhodnutí Soudního dvora (třetího senátu) ze dne 15. března 2012. SCF proti Marcu Del Corsovi. Věc C-135/10. Dostupné z: https://curia.europa.eu/juris/document/document.jsf?text $=\&$ docid $=120443 \&$ pageIndex $=0 \&$ doclang $=$ CS\&mode $=1$ st $\&$ dir $=\&$ occ $=$ first $\&$ part $=1 \&$ cid $=1232598$.

37 S ohledem na rozsah článku lze k bližšímu popisu definice PSSOO odkázat na SLIWKA, Rostislav. Poskytovatel služeb sdílení obsahu online dle směrnice (EU) 790/2019. Revue pro právo a technologie. [Online]. 2020, č. 21, s. 91-128. [cit. 2021-07-14]. Dostupné z: https://journals.muni.cz/revue/article/view/13228 
stejné publikum jako tyto služby. Mechanismus výjimek z odpovědnosti pro PSSOO by se pak neměl výslovně vztahovat na poskytovatele služeb, „jejichž hlavním účelem je provádět nebo usnadňovat pirátství.“ Posouzení PSSOO má být prováděno př́ípad od př́padu. ${ }^{38}$

Pokyny se dále věnují popisu jednotlivých definičních prvků, kdy především dovozují, že kritérium hlavního účelu PSSOO by mělo být vnímáno jako „hlavní nebo převládající funkce či úloha“ poskytovatele služby. Posouzení tohoto účelu by pak mělo být „neutrální z hlediska technologií a obchodního modelu.“ V otázce „uchovávání velkého počtu předmětů ochrany a jejich zpř́stupňováni" Pokyny dospívají $\mathrm{k}$ tomu, že pojem uchovávání by se měl vztahovat pouze na „delší než dočasné uchovávání obsahu.“ Stran kvantifikace velkého počtu předmětů ochrany Pokyny dospívají k tomu, že členské státy se mají bližšímu popisu tohoto pojmu v rámci implementace spíše vyhnout, nebơ dle recitálu 63 DSM směrnice je tento aspekt třeba posuzovat ,př́pad od př́padu a zohlednit při tom kombinaci prvků, jako je cílové publikum služby a celkový počet souborů nahraných uživateli. “" ${ }^{\text {(9) }}$

Závěrem Pokyny dospívají k závěru, že aspekt účelu zisku PSSOO by měl být posuzován jen ve vztahu k činnosti „uspořádávání a propagace obsahu, který byl nahráván uživateli, takovým způsobem, aby tento obsah přilákal širši publikum, mimo jiné např̌klad prostřednictvím umistění reklamy vedle obsahu, který jejich uživatelé nahráli." Výběr tzv. servisních poplatků či darů od uživatelů dle Pokynů účel zisku nenaplňuje. ${ }^{40}$

Český návrh novely AZ a OZ i zde v obecné rovině drží textaci DSM směrnice samotné. Oproti ní však opomíjí několik skutečností navrhovaných Komisí v Pokynech. Český návrh především v návrhu novely nijak neuvádí potřebu individuálního posouzení každého poskytovatele služeb, na které by mohla dopadat daná regulace. Tento aspekt je uveden pouze $\mathrm{v}$ důvodové zprávě. ${ }^{41} \mathrm{Z}$ českého návrhu pak navíc $\mathrm{v}$ průběhu legislativních prací v rámci úpravy vyplývající z připomínek Legislativní rady vlá-

\footnotetext{
38 Viz s. 4 Pokynů.

39 Viz s. 5 Pokynů.

40 Tamtéž.

41 Viz str. 46 důvodové zprávy.
} 
dy zmizel rovněž aspekt neuplatnění mechanismu vyloučení odpovědnosti dle čl. 17 DSM směrnice původně uvedený v § 47 odst. 4 návrhu novely AZ u služeb, jejichž hlavním účelem je provádět nebo usnadňovat pirátství. ${ }^{42}$ Český návrh pak nijak blíže, a to ani $\mathrm{v}$ důvodové zprávě, neřeší aspekt uchovávání obsahu.

Lze říci, že definice subjektů podléhajících režimu čl. 17 DSM směrnice, tj. tzv. PSSOO, je poměrně zásadním bodem celé nové úpravy. Právě zde množství poskytovatelů služeb hledalo prostor pro vyloučení aplikace režimu čl. 17 a uplatnění čl. 14 směrnice e-commerce. ${ }^{43}$

V kontextu Pokynů je na místě podrobit kritice několik skutečností. Předně je na místě souhlasit s Pokyny v tom směru, že implementační návrhy by měly výslovně vylučovat možnost omezení odpovědnosti dle čl. 17 odst. 4 DSM směrnice pro platformy založené na pirátství. Tato skutečnost vyplývá ze stávající judikatury Soudního dvora EU, přičemž i z recitálu 62 DSM směrnice lze dovodit, že u služby umožňující či usnadňující pirátství v oblasti práv duševního vlastnictví by mělo jít dovodit přímou odpovědnost platforem tohoto typu za sdělování veřejnosti. ${ }^{44} \mathrm{~V}$ tomto směru český návrh novely AZ oproti německému návrhu implementace zjevně pochybil. $^{45}$

Další oblastí, které je obzvláště v kontextu pandemické doby spojené $\mathrm{s}$ virem SARS-CoV-2 třeba věnovat pozornost, je aspekt uchovávání předmětů ochrany. Pokud totiž Pokyny dovozují, že je tím třeba rozumět delší než dočasné uchovávání obsahu, znamená to, že z působnosti režimu čl. 17 DSM směrnice vypadává tzv. live-streaming, který se stal relativně vyhledávanou alternativou pro živě vystupující umělce v době pandemických zá-

\footnotetext{
42 Viz str. 50 důvodové zprávy.

43 Viz SLIWKA, Rostislav, c.d., s. 24.

44 Viz SLIWKA, Rostislav, c.d., s. 36-37, recitál 62 DSM směrnice a Rozhodnutí Soudního dvora EU (druhého senátu) ze dne 14. června 2017. Stichting Brein proti Ziggo BV, XS4ALL Internet BV. Věc C-610/15. Dostupné z: https://curia.europa.eu/juris/document/document.jsf?text $=\&$ docid $=191707 \&$ pageIndex $=0 \&$ doclang $=$ CS\&mode $=1$ st $\&$ dir $=\& o c c=$ first \&part $=1 \& \operatorname{cid}=1539071$.

45 Viz Urheberrechts-Diensteanbieter-Gesetz - UrhDaG, § 1 odst. 4. Dostupné z: https:// www.bmjv.de/SharedDocs/Gesetzgebungsverfahren/Dokumente/UrhDaG_ENG.pdf? _blob $=$ publicationFile\&v $=3$.
} 
kazů živé kultury. ${ }^{46}$ Režimu čl. 17 tak dle Komise podléhá pouze tradiční uchování obsahu umožňující následné přehrání uživatelem v čase a místě, které si individuálně zvolí, tj. tzv. on-demand užití chráněného obsahu. V tomto směru je zajímavé zmínit implementaci DSM směrnice v Dánsku, která výslovně odkazuje jak na obecné sdělování veřejnosti, tak zpřístupňování veřejnosti ze strany PSSOO ve smyslu čl. 3 odst. 1 a 2 informační směrnice, z čehož lze dovodit i podřazení live-streamingu pod režim čl. 17 DSM směrnice. ${ }^{47}$ Tím spíše je zajímavá skutečnost, že český návrh novely AZ v podobě před připomínkovým řízením obsahoval stejnou úpravu, která byla později upravena ve výše uvedeném smyslu, tj. PSSOO provádí pouze sdělování díla veřejnosti dle $\S 18$ odst. $2 \mathrm{AZ}^{48}$ Tato změna však byla ze strany Ministerstva kultury ČR opomenuta v návrhu novely AZ v § $52 .{ }^{49}$ Tato legislativní pochybení jsou nevhodná, avšak z praktického pohledu lze uvést, že smyslem nové úpravy je především vzájemná spolupráce nositelů práv a PSSOO, kde je zachována smluvní volnost. Pokud proto nositel práv disponuje př́slušným oprávněním, nic dle mého názoru nebrání možnosti poskytnutí licence PSSOO zahrnující tzv. pass-through efekt i na užití formou live-streamingu. ${ }^{50}$ Zde je však třeba s ohledem na úpravu v českém au-

${ }^{46}$ Viz CISAC Global Collections Report 2020. cisac.org [online]. CISAC [cit. 14. 7. 2021]. s. 10. Dostupné z: https://www.cisac.org/services/reports-and-research.

${ }^{47}$ Informace autora $\mathrm{z}$ praxe. Tato úprava je uvedena v nově navrhovaném $§ 52 e$ dánského autorského zákona.

48 Viz $§ 18$ odst. 3 původního návrhu zákona, kterým se mění zákon č. 121/2000 Sb., o právu autorském, o právech souvisejících s právem autorským a o změně některých zákonů (autorský zákon), ve znění pozdějších předpisů, a další související zákony. apps.odok.cz [online]. Elektronická knihovna připravované legislativy pro veřejnost [cit. 14. 7. 2021]. Dostupné z: https://apps.odok.cz/veklep-history-version?pid=KORNBV4JQPRG： „Sdělováním díla verejnosti podle odstavce 1 nebo 2 je také zpř́stupňování díla verejnosti poskytovatelem služby pro sdílení obsahu online, bylo-li dílo nahráno uživatelem takové služby."

49 „Uděli-li autor poskytovateli služeb pro sdílení obsahu online oprávnění $k$ výkonu práva podle $\S 18$ odst. 1 nebo 2 , vztahuje se toto oprávnění rovněž na úkony podle $\S 18$ odst. 1 a 2 prováděné uživatelem takové služby, pokud tento uživatel nevykonává tyto úkony $v$ rámci svého podnikání nebo samostatného výkonu svého povolání nebo pokud tyto úkony nevytváríi významné príjmy."

${ }^{50}$ Srov. per analogiam Pokyny, s. 7: „Na druhé straně uživatelé, kteři jednají v rámci podnikatelské činnosti a/nebo získávají z obsahu, který nahráli, významné př́ijmy, by byli mimo oblast působnosti tohoto svolení nebo by se na ně nevztahovalo (pokud se strany výslovně smluvně nedohodly, že se na tyto uživatele bude vztahovat) [zvýrazněno autorem]. K pojmu pass-through efekt viz kapitola 2.3.4. 
torském zákoně uvést, že užití formou live-streamingu zpravidla zřejmě nebude obecným sdělováním veřejnosti ve smyslu $\S 18$ odst. $1 \mathrm{AZ}$, jak uváděl původní návrh novely $\mathrm{AZ}$, ale $\mathrm{v}$ závislosti na kontextu spíše přenosem živého provozování dle $\S 19$ odst. 2 AZ či vysíláním dle $\S 21$ AZ. ${ }^{51}$ Za zmínku stojí též právní rozbor Eleonory Rosati, která dospívá k tomu, že live-streaming režimu čl. 17 podléhá. ${ }^{52}$

\subsubsection{SVOLENÍ K UŽITÍ CHRÁNĚNÉHO OBSAHU DLE ČL. 17 ODST. 1 A 2}

Pokyny shodně s DSM směrnicí potvrzují, že PSSOO musí ke sdělování veřejnosti dle čl. 17 odst. 1 směrnice získat svolení nositele práv. Pokyny v tomto směru objasňují, že toto svolení není směrnicí nijak definováno, přičemž s odkazem na recitál 64 DSM směrnice je zřejmé, že tímto svolením není myšlena pouze licenční smlouva. ${ }^{53}$ Komise tudíž dospívá k tomu, že takové svolení může být řešeno individuálním licencováním, kolektivním licencováním, v režimu tzv. rozšířené kolektivní správy i prostřednictvím Creative Commons licencí. Pokyny dále akcentují smluvní svobodu nositelů práv, tj. i jejich možnost licenci platformě odmítnout. Zásadním momentem Pokynů je názor Komise, že svolení k užití sdělováním či zpřístupňováním veřejnosti zahrnuje též „rozmnoženiny nezbytné pro provádění těchto úkonů. Členské státy by neměly poskytovatelům služeb pro sdílení obsahu online ukládat povinnost získat svolení pro rozmnoženiny pořizované v kontextu, na nějž se vztahuje článek 17.“"

Český návrh novely AZ je v tomto směru poměrně lakonický, když pouze užití ze strany PSSOO v režimu čl. 17 DSM směrnice podřazuje pod $\S 18$ odst. 2 AZ. V kombinaci s $\S 12$ tak z daného vyplývá, že svolením v českém právu rozumíme „oprávnění k výkonu práva uděleným smlouvou“ či užití bez svolení v případech stanovených autorským zákonem. S ohledem na absen-

51 POLČÁK, Radim a kol. Autorský zákon. Praktický komentář s judikaturou. 1. vyd. Praha: Leges, 2020, s. 166-167. ISBN 978-80-7502-391-9.

52 ROSATI, Eleonora. Does the duration of the storage matter? Live streaming providers as 'online content sharing service providers' under Directive 2019/790. [online] 8 s. [cit. 2. 8. 2021]. Dostupné z: https://papers.ssrn.com/sol3/papers.cfm?abstract_id $=3594793$.

53 Recitál 64 DSM směrnice: „Poskytovatelé služeb pro sdílení obsahu online by proto měli od př́slušných nositelů práv získat svolení, a to i prostřednictvím licenční smlouvy.“

54 Pokyny, s. 6-7. 
ci daného způsobu užití v § 97d a § 97e AZ je pak zřejmé, že dané užití nespadá do režimu rozšířené či povinné kolektivní správy. Nicméně je možné, aby došlo k užití děl na daných platformách na základě nekomerčních licencí typu Creative Commons nebo na základě výjimek a omezení z autorského práva ve smyslu čl. 17 odst. 7 DSM směrnice a § 29 an. AZ. Důvodová zpráva $\mathrm{k}$ návrhu novely $\mathrm{AZ}$ pouze opisuje textaci DSM směrnice a jejích recitálů. ${ }^{55}$

K výše uvedenému je nutné uvést jednu zásadní kritickou poznámku. DSM směrnice v režimu čl. 17 zcela opomněla práva na rozmnožování, v licenční praxi nazývaná jako tzv. mechanická práva. V oblasti online užití je totiž praxí i teorií uznáváno, že při takovém užití zpravidla dochází jak k výkonu práv na sdělování veřejnosti (v praxi označovaná jako provozovací práva), tak práv na rozmnožování. Je pravdou, že úkony rozmnožování mohou být často pomíjivé povahy a $\mathrm{z}$ toho důvodu budou podléhat výjimce pro dočasné rozmnoženiny ve smyslu $\S 38 \mathrm{a} \mathrm{AZ}$. Nicméně i existence této výjimky je potvrzením, že k takovým úkonům dochází. Právě v režimu čl. 17, který zavádí tzv. pass-through účinek, ${ }^{56}$ je však evidentní, že uživatel platformy při nahrání díla provádí též úkon rozmnožení, který není dočasné povahy. I při samotné tvorbě obsahu pro nahrání na danou platformu pak zpravidla bude docházet k rozmnožování předmětů ochrany.

Ačkoliv v českém právu platí v určitých případech tzv. princip funkční jednoty užití ve smyslu $\S 2376$ odst. 2 OZ, tj. platí domněnka, že „licence byla poskytnuta $k$ takovým zpưsobům užití a $v$ takovém rozsahu, jak to je nutné k dosažení účelu smlouvy, “57 nelze dle mého názoru říci, že úkony rozmnožování jsou podřazeny pod sdělování či zpřístupňování díla veřejnosti ve smyslu čl. 3 informační směrnice. Tato směrnice výslovně v čl. 2 zavádí výlučné právo autora či jiného nositele práv udělit svolení k rozmnožování jeho předmětů ochrany. Nepostradatelná úloha mechanických a provozovacích práv při online užití je zřejmá např. u směrnice o KS, která v režimu

\footnotetext{
Viz s. 37 důvodové zprávy.

56 Viz kapitola 2.3.4.

57 TELEC, Ivo; TŮMA, Pavel. Autorský zákon: Komentáŕ. 2. vyd. Praha: C. H. Beck, 2019, s. 175. ISBN 978-80-7400-748-4.
} 
tzv. multiteritoriálního užití výslovně uvádí, že právy $\mathrm{k}$ hudebním dílům online se rozumí „práva autora $k$ hudebnímu dílu podle článkủ 2 a 3 směrnice 2001/29/ES, která jsou nezbytná k poskytování služby online. “58 Ačkoliv se tato úprava vztahuje pouze $\mathrm{k}$ hudebním dílům, není důvodu, proč by právo na rozmnožování mělo být $\mathrm{v}$ případě jiných předmětů ochrany nositelům práv pro licencování užití v režimu čl. 17 upřeno.

Tato skutečnost má pro praxi naprosto zásadní dopady, když licencování mechanických a provozovacích práv $\mathrm{v}$ oblasti hudebních děl na kolektivním základu je historicky velmi často odděleno. Ačkoliv značná část evropských kolektivních správců spravuje zpravidla oba druhy práv, v anglosaském prostředí platí, že mechanická práva zpravidla vykonává hudební nakladatel, zatímco práva provozovací vykonává autor, který je zpravidla svěří kolektivnímu správci. ${ }^{59}$ Komise tak v Pokynech uvádí, že:

„[...] hudební oblasti dnes někteř́ nositelé práv, jako jsou nahrávací společnosti, na svá vlastní práva zpravidla udēlují licence př́mo, stejně jako v př́padě, že jsou nositeli práv výkonných umèlců a hudebních vydavatelství, která jsou nositeli práv autorů (skladateli a textařù). Práva ostatních autorů jsou většinou spravována organizacemi kolektivní správy. “60

Ačkoliv má Komise $\mathrm{v}$ obecné rovině pravdu, anglosaští nakladatelé jakožto nositelé práv autorů vykonávají zpravidla práva mechanická, zatímco kolektivní správci spravují práva provozovací těchto autorů. DSM směrnice pak nikde neuvádí žádnou specifickou výjimku pro právo na rozmnožování při uplatňování režimu čl. $17 .{ }^{61}$ Lze proto konstatovat, že výše uvedené pochybení DSM směrnice je na místě určitým způsobem řešit. Domnívám se však, že nebylo úkolem Komise, aby se touto otázkou zabývala, nýbrž se

${ }^{58}$ Článek 3 písm. n) směrnice o KS. Viz též § 100 AZ.

59 MAZZIOTTI, Giuseppe. New Licensing Models for Online Music Services in the European Union: From Collective to Customized Management. [online]. s. 17 an. [cit. 10. 8. 2021]. Dostupné z: https://papers.ssrn.com/sol3/papers.cfm?abstract_id $=1814264$.

${ }^{60}$ Pokyny, s. 6-7.

61 „The Guidance text suggests an exception for reproduction right for the OCSSPs making protected works available, whereas this is mentioned nowhere in the Directive." Viz GESAC reacts to Article 17 Guidelines. authorsocieties.eu [online]. GESAC [cit. 20. 7. 2021]. Dostupné z: https://authorsocieties.eu/gesac-reacts-to-article-17-guidelines/. 
s tímto problémem měla vypořádat praxe, v nezbytném případě prostřednictvím předběžné otázky k Soudnímu dvoru EU.

Jistou polemiku lze vést i vůči českému návrhu novely AZ v tom směru, že čl. 17 odst. 1 DSM směrnice zmiňuje, že PSSOO provádí úkony sdělování a zpřístupňování předmětů ochrany veřejnosti ve smyslu čl. 3 odst. 1 a 2 informační směrnice, a tudíž $\mathrm{k}$ těmto úkonům musí získat svolení nositele práv. Český návrh nicméně odkazuje pouze na $\S 18$ odst. 2, který je provedením pouze čl. 3 odst. 2 informační směrnice, tj. zavádí právo na zpřístupňování předmětu ochrany veřejnosti takovým zpơsobem, „že kdokoli může mít $k$ němu přistup na místě a $v$ čase podle své vlastní volby zejména počítačovou nebo obdobnou síti.“

Samotná DSM směrnice je v tomto ohledu rozporuplná, když definici PSSOO vztahuje v čl. 2 především na poskytovatele, kteří uchovávají a zpř́stupňují předměty ochrany veřejnosti, ačkoliv čl. 17 odkazuje kromě zpřístupňování předmětů ochrany též na obecné sdělování veřejnosti ve smyslu čl. 3 informační směrnice a $\S 18$ odst. $1 \mathrm{AZ}$. Tento aspekt se právě v českém návrhu projevuje jasně v juxtapozici navrhovaných $\S 46$ an. AZ a $\S 52 \mathrm{AZ}$, viz následující kapitola.

\subsubsection{SVOLENÍ K UŽITÍ CHRÁNĚNÉHO OBSAHU ZAHRNUJÍCÍ UŽIVATELE} $\mathrm{V}$ jistém smyslu lze dospět $\mathrm{k}$ tomu, že efekt tzv. pass-through licence ve smyslu čl. 17 odst. 2 je zcela ústředním prvkem celého čl. 17. Tato úprava stanoví, že svolení, resp. licence udělená PSSOO se vztahuje „rovněž na úkony prováděné uživateli služeb, na něž se vztahuje článek 3 směrnice 2001/29/ ES, pokud nejednají v rámci podnikatelské činnosti a pokud jejich činnost nevytváří významné př́immy. "Právě tento moment nejvíce odlišuje novou úpravu od dosavadního právního stavu, kdy odpovědnost platforem za činnost svých uživateli̊ byla dovozována pouze v sekundární rovině, tj. až jako odpovědnost za porušení podmínek tzv. bezpečných přístavi̊ ve smyslu čl. 12 až 14 směrnice e-commerce.

Pokyny Komise roli čl. 17 odst. 2 DSM směrnice projevují tím, že apelují na členské státy, aby danou úpravu provedly výslovně ve vnitrostátním zákonodárství. Komise se následně zabývá bližší definicí uživatelů, na něž se 
pass-through efekt vztahuje - tj. uživatelů, kteří jednají pro nekomerční účely nebo jejichž aktivita negeneruje významné př́ijmy. V prvním případě Komise uvádí např. domácí videa, v druhém případě pak instruktážní videa, která vytvářejí omezený př́ijem z reklamy. Komise zmiňuje, že členské státy by neměly pojem významných př́ijmů nijak kvantifikovat, nebot je třeba jej zkoumat případ od případu. Komise též uvádí poměrně zásadní aspekt, a to skutečnost, že „neplatí domněnka ve prospěch poskytovatelů služeb pro sdílení obsahu online, že uživatelé vždy mají všechna nezbytná svolení pro obsah, který nahrávají. "Důležitým bodem je též úvaha nad tím, že je na dohodě nositelů práv a PSSOO, zda pass-through efekt vztáhnou i na ostatní uživatele platformy, tj. zejména na profesionální uživatele generující větší příjmy z nahrávaného obsahu. ${ }^{62}$

Český návrh novely AZ tento režim výslovně provedl v navrhovaném $\S 52$ AZ, který uvádí:

„Udělí-li autor poskytovateli služeb pro sdílení obsahu online oprávnění $k$ výkonu práva podle $\S 18$ odst. 1 nebo 2, vztahuje se toto oprávnění rovněž na úkony podle $\S 18$ odst. 1 a 2 prováděné uživatelem takové služby, pokud tento uživatel nevykonává tyto úkony $v$ rámci svého podnikání nebo samostatného výkonu svého povolání nebo pokud tyto úkony nevytváří významné př́ijmy. “

Jak již jsem avizoval výše, domnívám se, že zde došlo k pochybení českého zákonodárce a zmatení se v nepř́liš jednoznačném znění DSM směrnice, když zde uvádí poskytnutí licence pro užití dle $\S 18$ odst. 1 AZ, které v ostatních ustanoveních návrhu novely neuvádí a i v důvodové zprávě k návrhu uvádí jen $\S 18$ odst. 2 AZ. Užití dle $\S 18$ odst. 1 AZ je totiž tzv. lineární povahy, tedy chybí zde interaktivní aspekt typický pro užití dle $\S 18$ odst. 2 AZ. Danou úpravou bychom mohli např. dospět $\mathrm{k}$ tomu, že pod režim čl. 17 lze zařadit např. tzv. live-streaming. ${ }^{63}$

Pozitivem Pokynů je nicméně závěr, že PSSOO a nositelé práv mohou smluvně dojednat uplatnění pass-through efektu též na profesionální uživa-

\footnotetext{
62 Pokyny, s. 7-8.

63 Viz kapitola 2.3.2 a návrh podřazení live-streamingu pod režim čl. 17 DSM směrnice v Dánsku.
} 
tele platforem. Domnívám se, že v praxi bude odlišení jednotlivých kategorií uživatelů leckdy obtížné a tudíž uznání smluvní svobody dotčených subjektů je v tomto směru zcela na místě.

\subsubsection{ODPOVĚDNOST POSKYTOVATELŮ SLUŽEB SDÍLENÍ OBSAHU ONLINE V PŘÍPADĚ NEEXISTENCE SVOLENÍ DLE ČL. 17 ODST. 4}

Pokyny v této zcela zásadní oblasti v obecné rovině kopírují textaci DSM směrnice. Nad její rámec nicméně uvádějí zásadní premisu nové úpravy v čl. 17 DSM směrnice:

„Zvláštní mechanismus odpovědnosti podle čl. 17 odst. 4 se použije pouze $v$ př́ípadě, že není uděleno svolení ke sdělením veřejnosti prováděným poskytovateli služeb pro sdílení obsahu online $v$ souvislosti s úkony jejich uživatelů ve smyslu čl. 17 odst. 1. Čím více svolení tedy bude poskytnuto podle čl. 17 odst. 1 a 2, tím méně často bude nutné využívat mechanismus podle čl. 17 odst. 4. “64

Tato skutečnost byla často akcentována nositeli práv, kteří tím naznačovali, že hlavním cílem nové úpravy není zavádět cenzuru či filtrování internetu, ale naopak zajistit dostupnost obsahu jeho licencováním. ${ }^{65}$ Tedy Komise zdưrazňuje, že poměrně komplexní mechanismus vylučování odpovědnosti PSSOO je zamýšlen až jako pojistka pro případ, že PSSOO nevynaloží veškeré úsilí k získání svolení k užití. K pojmu veškerého úsilí pak Komise dodává, že tento pojem není nijak definován a není proveden žádný odkaz na vnitrostátní právo, tudíž je veškeré úsilí v tomto kontextu autonomním pojmem práva EU. ${ }^{66}$

K dané problematice je aktuálně pozornost upřena $\mathrm{k}$ polské žalobě ve věci C-401/19 na zrušení čl. 17 odst. 4 písm. b) a c) in fine, popř., celého čl. 17 DSM směrnice. V této věci již bylo k 15. červenci 2021 vydáno stanovisko generálního advokáta. ${ }^{67}$

64 Pokyny, s. 8.

65 Viz prezentace společnosti GESAC ze 4. jednání Stakeholders Dialogue [online]. Evropská komise [cit. 28. 7. 2021]. Dostupné z: https://digital-strategy.ec.europa.eu/en/events/ fourth-meeting-stakeholder-dialogue-article-17-directive-copyright-digital-single-market.

66 Pokyny, s. 9. 
K první podmínce vyloučení odpovědnosti PSSOO dle čl. 17 odst. 4 písm. a) DSM směrnice, tj. k požadavku na vynaložení veškerého úsilí k získání svolení, Pokyny připomínají, že je třeba její naplnění posuzovat případ od případu a měly by být zohledněny specifické tržní podmínky, např. zda je v dané oblasti rozšířena kolektivní správa. Komise dospívá k tomu, že minimálním standardem pro naplnění této podmínky je aktivní kontakt s nositeli práv, které lze snadno identifikovat - tak je tomu obzvláště v případě kolektivních správců, kteří pro svoji činnost naplňují podmínky dle směrnice o KS. ${ }^{6}$

Pokyny na druhou stranu uvádějí, že zásada proporcionalita stanovená $\mathrm{v}$ čl. 17 odst. 5 DSM směrnice nemůže vést $\mathrm{k}$ tomu, že PSSOO bude vyhledávat nositele práv, které „podle všech rozumných měřítek nelze snadno určit.“ Členské státy jsou tak nabádány $\mathrm{k}$ tomu, aby např. vytvářely registry nositelů práv pro nahlédnutí ze strany PSSOO. U menších poskytovatelů služeb Pokyny konstatují, že tito by měli především poskytovat jasné kontaktní údaje či nástroje, aby je mohli př́islušní nositelé práv oslovit. ${ }^{69}$

Komise se závěrem zabývá samotnou licenční negociací. Akcent je tudíž kladen na jednání v dobré víře a na uzavírání smluv obsahujících spravedlivé a přiměřené podmínky, kterými se rozumí i přiměřená odměna. ${ }^{70}$ Uzavřené smlouvy by měly rovněž vést $k$ transparentnosti PSSOO, pokud jde o identifikaci obsahu na platformě, která slouží k vykazování užití licencovaného obsahu a tudíž může mít i vliv na konečnou odměnu pro nositele práv. Jakmile PSSOO odmítne uzavřít licenční smlouvu, která obsahuje spravedlivé a přiměřené podmínky, nevynaložil veškeré úsilí k získání svolení. Při jednání s kolektivními správci se uplatní čl. 16 směrnice o KS, tedy

\footnotetext{
${ }^{67}$ Stanovisko generálního advokáta Henrika Saugmandsgaarda Øe přednesené dne 15. července 2021. Polská republika proti Evropskému parlamentu a Radě Evropské unie. Věc C401/19. Dostupné z: https://curia.europa.eu/juris/document/document.jsf? text $=$ \&docid $=244201 \&$ pageIndex $=0 \&$ doclang $=\mathrm{CS} \&$ mode $=$ req\&dir $=\&$ occ $=$ first $\&$ part $=$ $1 \&$ cid = 1501914 (dále jen „stanovisko GA k polské žalobě“).

68 Pokyny, s. 9.

69 Tamtéž, s. 9-10.

70 Srov. čl. 18 an. DSM směrnice.
} 
licenční podmínky, včetně odměny, musí být založeny na objektivních a nediskriminačních kritériích. ${ }^{71}$

Český návrh novely AZ je poměrně stručný a spíše opisuje textaci DSM směrnice. ${ }^{72}$ Odlišností je nicméně užití pojmu „nejlepši úsilit“ oproti oficiálnímu českému znění, které užívá pojem „veškeré úsilī“, které je překladem anglického „best efforts“. Ministerstvo kultury tuto změnu vysvětluje připomínkami dotčených subjektů a komentáři v rámci meziresortního připomínkového řízení. Ministerstvo dále rozvádí:

„Pod pojmem „nejlepši úsilī“ si lze představit, jak tento pojem shodně chápaly členské státy i Evropská komise na konzultačních jednáních ke směrnici, „řádnou odbornou péči, kterou je možno požadovat od profesionála“, resp. shodně s bodem 66 odůvodnění směrnice „veškeré kroky, které by učinil pečlivý hospodář“، “73

Důvodová zpráva pak obdobně jako Pokyny konstatuje požadavek na jednání v dobré víře a uzavírání licenčních smluv za spravedlivých a přiměřených podmínek. Rovněž tak zmiňuje požadavek transparentnosti PSSOO vůči nositelům práv. Důvodová zpráva nakonec potvrzuje, že i při splnění podmínky v čl. 17 odst. 4 písm. a) musí PSSOO splňovat i podmínky $\mathrm{v}$ bodech b) a c); platí přitom smluvní svoboda jak na straně nositeli̊ práv, tak na straně PSSOO. ${ }^{74}$

Pozitivem Pokynů i důvodové zprávy k návrhu novely $\mathrm{AZ}$ a OZ je především požadavek transparentnosti PSSOO a určitý tlak na zajištování licencí ze strany PSSOO vyvážený korektivy přiměřených a spravedlivých podmínek a jednání s nositeli práv v dobré víře. Tyto základní principy musí nicméně prozařovat v praxi celým režimem čl. 17 DSM směrnice. Je tedy třeba brát v potaz, že ačkoliv je smluvní svoboda zásadním principem, při neuzavření návrhu licenční smlouvy, kterou předloží platformě nositel práv a která obsahuje přiměřené a spravedlivé podmínky, ze strany PSSOO,

\footnotetext{
71 Pokyny, s. 10-11. Pokyny správně zmiňují i možnost individuálních licencí pro inovativní platformy, srov. čl. 16 odst. 2, druhá věta směrnice o KS a $\S 98$ odst. 5 AZ.

72 Viz § 47 odst. 1 písm. a) návrhu novely AZ.

73 Důvodová zpráva k návrhu novely $\mathrm{AZ}$ a OZ, s. 52.

74 Tamtéž, s. 52-53.
} 
je daný poskytovatel odpovědný za neoprávněné sdělování veřejnosti, nebot nenaplnil podmínku vynaložení veškerého úsilí k získání svolení $\mathrm{k}$ užití daného obsahu. Není poté možné vyžadovat po nositeli práv, aby se aktivně domáhal dalšího postupu v bodech b) a c) (tj. staydown a takedown procedur), pokud sám oslovil platformu za účelem uzavření licenční smlouvy obsahující spravedlivé a přiměřené podmínky. $\mathrm{V}$ takovém případě by proto měl PSSOO odpovídat za neoprávněné užití. Tato skutečnost vyplývá ze samotné formulace čl. 17 odst. 4 DSM směrnice, který dané podmínky vyloučení odpovědnosti formuluje kumulativně.

Kladně pak lze hodnotit výslovné uvedení kolektivních správců jakožto subjektů, které by měl PSSOO v každém prrípadě oslovit a vést $\mathrm{s}$ nimi jednání o licenční smlouvě, aby splnil alespoň minimální standard vynaložení veškerého úsilí $\mathrm{k}$ zajištění svolení $\mathrm{k}$ užití. Domnívám se však, že $\mathrm{v}$ tomto směru mohly jít Pokyny i důvodová zpráva $\mathrm{k}$ českému návrhu dále a zmínit též tzv. nezávislé správce práv ve smyslu čl. 3 písm. b) směrnice o KS a § 104 an. AZ, kteří musí splňovat určité zákonné podmínky a zpravidla se též registrovat u přislušných vnitrostátních orgánů dohledu.

Jistou kritiku lze však vytknout $\mathrm{v}$ př́padě Pokynů a jejich závěru, že u menších poskytovatelů služeb lze předpokládat, že pro vynaložení veškerého úsilí k získání svolení osloví jen př́slušné kolektivní správce a „př́padně několik dalš̌́ch nositelů práv, které lze snadno určit." U těchto poskytovatelů dle Pokynů byl mělo $\mathrm{v}$ rozsahu zbývajících nositelů práv postačit zveřejnit kontaktní údaje na platformu či jiný kontaktní nástroj. ${ }^{75}$ Ačkoliv tento závěr vychází z požadavku proporcionality, domnívám se, že je tento závěr zavádějící a jde spíše proti smyslu čl. 17 DSM směrnice, který předpokládá jistou aktivitu poskytovatelů služeb. Pokyny navíc nijak neurčují, který poskytovatel je menší či větší. Vzhledem $\mathrm{k}$ tomu, že směrnice samotná zavádí mírně odlišný režim pro tzv. startupy dle čl. 17 odst. 6 , vyvolává výše uvedené otázku, zda tím Komise nevytváří další podkategorii PSSOO. Směrnice pouze konkrétně stanoví, na co je třeba hledět $\mathrm{k}$ posouzení odpovědnosti v rámci uplatnění principu proporcionality dle čl. 17

\footnotetext{
75 Pokyny, s. 10.
} 
odst. 5. Postup Komise v Pokynech tudíž nepovažuji za vhodný, nebot’ vytváří právní nejistotu.

K druhé podmínce vyloučení odpovědnosti PSSOO, tj. k „vynaložení veškerého úsilí $k$ zajištění nedostupnosti konkrétních děl a jiných předmětů ochrany, o nichž mu nositelé práv poskytli relevantní a nezbytné informace," v souladu s vysokými odvětvovými standardy odborné péče jsou Pokyny poměrně detailní.

Komise se nejprve zabývá aspektem relevantních a nezbytných informací, které musí nositel práv platformě k uplatnění této notice-and-staydown procedury dodat, aby mohla platforma vi̊bec jednat. Dle Komise je tyto informace třeba posuzovat případ od případu. Nositelé práv mohou tyto informace poskytovat PSSOO i prostřednictvím třetích stran. K Relevantnosti informací Komise uvádí, že by informace nositele práv měla být přinejmenším přesná, pokud jde o vlastnická práv k předmětům ochrany. Nezbytnost informací se bude dle Komise posuzovat s ohledem na to, jakou konkrétní technologii rozpoznávání obsahu ve smyslu vysokých odvětvových standardi̊ bude daná platforma uplatňovat. Informace pak musí být platformě poskytnuty předem. $^{76}$

Komise v této oblasti dovozuje též možnost nositelů práv předem označovat předměty ochrany, jejichž neoprávněné užití na dané platformě jim může způsobit závažnou újmu, tj. jde o tzv. „pre-flagging“. Dle Komise může jít o faktor při posuzování vynaložení veškerého úsilí k zajištění nedostupnosti obsahu dodržování záruk pro oprávněná užití v čl. 17 odst. 7 DSM směrnice. ${ }^{77}$

Velkým tématem v souvislosti s podmínkou v čl. 17 odst. 4 písm. b) DSM směrnice bylo zejména to, jakou technologii musí PSSOO implementovat, aby tuto podmínku naplnil. Komise proto v Pokynech vychází zejména z dialogu zúčastněných stran, který byl veden na základě čl. 17 odst. 10 směrnice a který měl odhalit již funkční a uplatňované technologie $\mathrm{v}$ r. 2020. ${ }^{78}$ Komise úvodem zdůrazňuje, že implementace čl. 17 odst. 4 písm. b)

\footnotetext{
76 Pokyny, s. 11-12, 13-14.

77 Pokyny, s. 15.
} 
má být co nejvíce technologicky neutrální, aby zůstala platná i v budoucnu. $^{79}$

Komise se dále snaží s odkazem na recitál 66 DSM směrnice vypořádat s pojmem vysokých odvětvových standardů odborné péče. Dle jejího názoru je třeba vycházet $\mathrm{z}$ technických řešení dostupných na trhu k aktuálnímu okamžiku, což by však nemělo omezovat PSSOO v zavedení technického řešení, které danou povinnost u konkrétní platformy naplní. Tj. i zde je kladen akcent na proporcionalitu. ${ }^{80}$ Komise v souladu s tímto principem dovozuje, že při aplikaci kritéria dle čl. 17 odst. 4 písm. b) DSM směrnice bude třeba zvážit několik prvků - druh a rozsah služby a její cílové publikum; dostupnost vhodných a účinných technických prostředků a související náklady; a druh obsahu nahraného uživateli. ${ }^{81}$

Pokyny slovy Komise nedávají doporučení k užití konkrétní technologie, nebot by zúčastněným stranám měla být ponechána flexibilita, aby se dohodly na oboustranně výhodných podmínkách a způsobech zajištění nedostupnosti obsahu. Komise proto pouze shrnuje, které technologie byly ze strany zúčastněných stran uvedeny jako aktuálně využívané. Platí, že rozpoznávání obsahu v té či oné míře je již běžným postupem u těch poskytovatelů služeb, kteří již nyní uzavírají licenční smlouvy s nositeli práv a tyto technologie užívají k identifikaci užitého obsahu za účelem kalkulace odměny. Častou metodou v oblasti video a audio obsahu je tzv. snímání otisků, tj. porovnání otisků chráněných děl poskytnutých nositeli práv s nahrávaným obsahem. Dalšími metodami jsou hašování, užití vodoznaků či metadat, vyhledávání podle klíčových slov a různé kombinace technologií. Komise nicméně připouští, že u některých druhů obsahu bude docházet k tomu, že k zabránění užití bude docházet jen na základě oznámení nositelů práv ve smyslu čl. 17 odst. 4 písm. c) DSM směrnice. Tak tomu může být

\footnotetext{
${ }^{78}$ Pro veškerá jednání dialogu a prezentace zúčastněných stran viz Stakeholder dialogue on copyright. digital-strategy.ec.europa.eu [online]. Evropská komise [cit. 25. 7. 2021]. Dostupné z: https://digital-strategy.ec.europa.eu/en/policies/stakeholder-dialoguecopyright.

79 Pokyny, s. 12.

80 Tamtéž.

81 Tamtéž, s. 13-14.
} 
např. u některých autorských děl $\mathrm{z}$ oblasti výtvarného umění, u nichž zatím nejsou dostupné vhodné technologie $\mathrm{k}$ rozpoznání obsahu. ${ }^{82}$ Tuto možnost ostatně připouští i recitál 66 DSM směrnice. ${ }^{83}$

I zde se český návrh novely $\mathrm{AZ}$ a $\mathrm{OZ}$ drží textace směrnice a s výjimkou uvedení nejlepšȟho úsilí namísto veškerého úsilí nijak nevybočuje, tedy v tomto směru je souladně s Pokyny technologicky neutrální a ponechává prostor pro praxi $\mathrm{k}$ uplatnění vlastních postupů. ${ }^{84}$ Důvodová zpráva je zde poměrně stručná a odkazuje na v té době teprve připravované Pokyny. ${ }^{85}$

Polská žaloba k Soudnímu dvoru EU ve věci C-401/19 v tomto ohledu argumentovala tím, že čl. 17 odst. 4 písm. b) a c) vedou nezbytně k potřebě ex ante filtrování veškerého obsahu na dané platformě, resp. i k jeho blokování, a tudíž jde o nepřiměřený zásah do práva na svobodu projevu dle čl. 11 LZPEU. Generální advokát Øe se s tímto posouzením neztotožnil. Ve svém stanovisku uvádí, že určité technologické nástroje rozpoznávání obsahu se objevují již od nultých let 21 . století, přičemž DSM směrnice tento vývoj pouze reflektovala a měla za cíl „upravit povinnost poskytovatelů služeb pro sdílení zavést takové nástroje, a sice ty, kteří tak dosud neučinili, přimět $k$ tomu, aby se „modernizovali“ a ty ostatní zavázat $k$ tomu, aby nositelüm práv poskytli transparentní př́stup $k$ jejich nástrojům pro rozpoznávání. “86 Ačkoliv výsledná podoba ustoupila od výslovného uvedení „automatického rozpoznávání obsahu“ ", ${ }^{87}$ dle názoru polské vlády k povinnosti zavést takové mechanismy tlačí PSSOO nepřímo. Generální advokát však dospěl k tomu, že takovou povinnost směrnice neobsahuje a konstatoval, že je zřejmé, „že ve všech př́padech, $k d y$ jsou na trhu $k$ dispozici různé vhodné a účinné nástroje, které nejsou nepřiměřeně nákladné, jsou posky-

${ }^{82}$ Tak tomu může být např. u děl sochařských či architektonických.

${ }^{83}$ Pokyny, s. 12-13.

${ }^{84}$ Viz § 47 odst. 1 písm. b) návrhu novely AZ.

85 Důvodová zpráva k návrhu novely AZ a OZ, s. 53-54.

86 Body 57-59 odůvodnění stanoviska GA k polské žalobě.

87 Srov. čl. 13 návrhu směrnice Evropského parlamentu a Rady o autorském právu na jednotném digitálním trhu - COM/2016/0593 final - 2016/0280 (COD). In: EUR-Lex [právní informační systém]. Úřad pro publikace Evropské unie [cit. 25. 7. 2021]. Dostupné z: https://eur-lex.europa.eu/legal-content/CS/ALL/?uri=CELEX\%3A52016PC0593. 
tovatelé služeb pro sdílení povinni a priori je zavést, aby prokázali, že vynaložili „veškeré úsili“", aby zabránili zpř̌stupnění protiprávního obsahu online, a že tedy napadená ustanovení dodrželi. V souladu se zásadou proporcionality si př́padně mohou zvolit mezi dostupnými nástroji ty nástroje, které nejlépe odpovídají jejich situaci a zdrojům, kterými disponují - nebo, v prŕpadě těch nejmajetnějších z nich, dokonce takové nástroje vyvinout interně. “88

Daná oblast je značně komplikovaná a je třeba $\mathrm{k}$ ní uvést několik kritických poznámek. Komise zmiňuje, že nositelé práv mohou platformě oznámit předměty ochrany, jejichž dostupnost na platformě jim může způsobit značnou újmu. Tato varianta je problematická $\mathrm{v}$ tom směru, že zásadním principem autorského práva je především výlučné právo autora dovolit či zakázat užití svého díla. Pokud tedy nesouhlasí s užitím jakýchkoliv svých děl na určité platformě, není smysluplné mu umožňovat označit konkrétní díla, u nichž dostupnost na platformě způsobí závažnou újmu a u nichž nikoliv. Lze si představit postup nositelů práv, že preventivně takto označí všechna svá díla. $\mathrm{V}$ tomto směru je např. zásadní praxe kolektivních správců, kteří mají ze zákona povinnost rovného zacházení jak $\mathrm{k}$ nositelům práv, tak $\mathrm{k}$ jednotlivým dílům. Kolektivní správci tak ani takto označovat konkrétní díla ze svého repertoáru nemohou, bez ohledu na to, zda určitá díla přinášejí větší hospodářský prospěch z užití než ostatní - kolektivní správce takto může označit bud' všechna díla ze svého repertoáru, nebo žádné. Pokyny bohužel daný závěr využívají též při postupech dle čl. 17 odst. 7 a 9 DSM směrnice. ${ }^{89}$

Problematickým je dále požadavek prokázání vlastnictví práv. Autorské právo $\mathrm{k}$ dílu vzniká již $\mathrm{k}$ okamžiku, kdy bylo dílo poprvé vyjádřeno $\mathrm{v}$ jakékoli objektivně vnímatelné podobě. ${ }^{90}$ Originární nositel práv ve smyslu tvůrce díla tak stojí před obtížnou otázkou, jakým způsobem vůči PSSOO prokáže své autorství a svůj právní titul k výkonu majetkových práv autorských. Tento požadavek lze chápat u vykonavatelů autorských práv

\footnotetext{
88 Bod 68 odůvodnění stanoviska GA k polské žalobě.

89 Viz kapitola 2.3.7.

${ }^{90}$ Viz $§ 9$ odst. 1 AZ.
} 
majetkových na základě smluv, jakou jsou odvození nositelé práv ve smyslu $\S 95$ odst. 3 písm. c) AZ, nebo u kolektivních správců. Pokud však přijmeme premisu, že i originární nositel práv musí prokazovat své vlastnictví, znamená to, že i např. kolektivní správce by musel prokázat, že nositel práv, jehož práva k danému dílu spravuje, toto dílo opravdu vytvořil? Ad absurdum je zjevné, že tento požadavek je pro praxi zcela nevhodný.

Pozitivem je alespoň závěr Komise, že PSSOO i nositelům práv by měla být ponechána flexibilita $\mathrm{v}$ uplatňování technologických postupů, na nichž naleznou shodu v licenční praxi. Obzvláště v hudebním a audiovizuálním sektoru již taková shoda často existuje.

U třetí, poslední podmínky vyloučení odpovědnosti PSSOO, tj. prokázání, že PSSOO, ihned poté, co obdrží dostatečně odůvodněné oznámení od nositele práv, zamezil př́stup k oznámeným předmětům ochrany nebo je odstranili ze svých webových stránek, a že vynaložil veškeré úsilí k zamezení jeho budoucímu nahrání v souladu s čl. 17 odst. 4 písm. b) DSM směrnice, jsou Pokyny poměrně stručné. Přehledně však shrnují situace, u nichž může dojít k postupu dle čl. 17 odst. 4 písm. c) směrnice, pokud nebylo uděleno svolení $\mathrm{k}$ užití.

Předně jde o situaci, kdy nositelé práv neposkytli platformě ex ante relevantní a nezbytné informace dle čl. 17 odst. 4 písm. b) směrnice a konají až ex post poté, co se daný obsah stal dostupným. Druhá situace nastane v př́padě, kdy PSSOO vynaloží veškeré úsilí k zamezení dostupnosti obsahu dle čl. 17 odst. 4 písm. b) směrnice, ale obsah se z objektivních důvodů stane dostupným, např. z důvodu technologického omezení. Za třetí jde o specifické případy, kdy bude PSSOO vůči danému obsahu jednat až po oznámení od nositelů práv v souladu s recitálem 66 směrnice. ${ }^{91}$ Komise pak v souladu s čl. 17 odst. 8 směrnice připomíná, že uplatňování čl. 17 nicméně nesmí vést $\mathrm{k}$ obecné povinnosti dohledu a musí zajištovat možnost oprávněných užití na základě výjimek a omezení z autorského práva. ${ }^{92}$

Nejzásadnějším momentem Pokynů je v tomto směru požadavek na důsledné odlišování relevantních a nezbytných informací ve smyslu staydown

91 Pokyny, s. 15.

92 Tamtéž, s. 16. 
procedury v čl. 17 odst. 4 písm. b) DSM směrnice a dostatečně odůvodněného oznámení ve smyslu odst. 4 písm. c). $\mathrm{V}$ druhém př́ípadě Komise odkazuje na Doporučení Komise o opatřeních pro efektivní boj proti nezákonnému obsahu online z r. 2018. ${ }^{93}$ Komise tak shrnuje, že daná oznámení by „měla být dostatečně přsná a řádně odưvodněná, tak aby poskytovatelé služeb [mohli] informovaně a s náležitou péčí rozhodnout o obsahu, $k$ němuž se oznámení vztahuje, zejména pokud jde o to, zda je obsah nutné považovat za nezákonný. Oznámení by zejména mèla obsahovat [vysvětlení] důvodů, které vedou oznamovatele k názoru, že se jedná o nezákonný obsah, a [jasný popis] umístění tohoto obsahu. Tyto konkrétní informace by nemusely být nutně vyžadovány podle čl. 17 odst. 4 pism. b), měly by však být zpravidla vyžadovány podle čl. 17 odst. 4 písm. c) první části. “94

U odkazu na čl. 17 odst. 4 písm. b) pak Komise dospívá k tomu, že relevantní a nezbytné informace k zamezení budoucího nahrání předmětů ochrany zahrnují stejné informace jako při postupu dle odkazovaného ustanovení. To dle Komise znamená např. To, že „pokud poskytovatel služeb používá $k$ zamezení budoucího nahrávání oznámených dèl technologie snímání otisků, nestačilo by obdržet pouze informace poskytnuté $v$ oznámení. $v$ tomto př́padě, aby se poskytovatelům služeb umožnilo zamezit budoucím nahráním oznámených děl, museli by nositelé práv poskytnout poskytovatelům služeb otisky nebo soubory obsahu. “95

Český návrh novely $\mathrm{AZ}$ a OZ je i zde věrný textaci DSM směrnice a s výjimkou pojmu nejlepšího úsilí, jak uvedeno výše, pouze směrnici kopíruje. ${ }^{96}$

\footnotetext{
93 Doporučení Komise (EU) 2018/334 ze dne 1. března 2018 o opatřeních pro efektivní boj proti nezákonnému obsahu online. In: EUR-Lex [právní informační systém]. Úřad pro publikace Evropské unie [cit. 25. 7. 2021]. Dostupné z: https://eur-lex.europa.eu/legalcontent/CS/TXT/HTML/?uri = CELEX:32018H0334\&from = CS (dále jen „doporučení Komise").

94 Pokyny, s. 16.

95 Pokyny, s. 17.

${ }^{96}$ Viz $§ 47$ odst. 1 písm. c) návrhu novely AZ.
} 
Rovněž tak důvodová zpráva $\mathrm{k}$ návrhu novely je velmi stručná a neuvádí nic nad rámec či v rozporu s Pokyny. ${ }^{97}$

V obecném smyslu lze souhlasit $\mathrm{s}$ tím, že samotná DSM směrnice oba módy poskytování informací ze strany nositelů práv formuluje odlišně a v jiném kontextu a lze chápat též závěr Pokynů, které uvádějí, že relevantní a nezbytné informace ze strany nositele práv musejí být poskytnuty ve formátu, který umožní efektivní zamezení opětovnému nahrání obsahu na platformě v souladu s uplatněnou technologií ze strany PSSOO. Spatřuji zde však určitá rizika.

Tím prvním je požadavek, aby relevantní a nezbytné informace od nositele práv respektovali užitou technologii rozpoznávání obsahu ze strany PSSOO. Ačkoliv $\mathrm{v}$ prrípadě kolektivních správců a jiných nositelů práv s právy $\mathrm{k}$ velkému množství obsahu (vydavatelé či nakladatelé) bude možné výše uvedené dodržet, a to i s ohledem na požadavek DSM směrnice na společné jednání PSSOO a nositelů práv za účelem navázaní spolupráce i vưči užitým technologiím, bude obtížné si představit např. požadavek na individuálního nositele práv, aby platformě zaslal tzv. haše svých skladeb či jiný technický prvek. Domnívám se, že toto vyjádření Komise směřuje k určité monopolizaci či větší agregaci práv na straně nositelů práv, která individuální nositele práv může fakticky odkazovat pouze $\mathrm{k}$ uplatňování notice-and-takedown procedury, která je v podstatě vrátí do režimu směrnice e-commerce.

Jako druhé negativum vnímám odkaz Komise na své dřívější doporučení z r. 2018 u dostatečně odůvodněného oznámení ve smyslu čl. 17 odst. 4 písm. c) DSM směrnice. Je totiž třeba vnímat to, že dané doporučení se zabývá obecně jakýmkoliv protiprávním obsahem na internetu od terorismu a dětské pornografie přes difamaci fyzických osob až k porušování práv duševního vlastnictví. $\mathrm{V}$ některých případech může být obtižné na první pohled posoudit, zda je daný obsah skutečně protiprávní. ${ }^{98}$ Doporučení Komise proto ve svém čl. 6 uvádí, že oznámení mají být „dostatečně přesná a odůvodněná, tak aby dotčený poskytovatel hostingových služeb mohl informovaně a s náleži-

97 Důvodová zpráva k návrhu novely AZ a OZ, s. 54.

98 Tak tomu může být např. u difamujících prohlášení či u zásahu do soukromí v případě exponovaných politiků oproti běžným osobám. 
tou péči rozhodnout o obsahu, $k$ němuž se oznámení vztahuje, zejména pokud jde o to, zda je obsah nutné považovat za nezákonný a je třeba ho odstranit nebo znepř́stupnit.“ Lze tudíž chápat požadavek na dostatečné a věcné odůvodnění oznámení.

DSM směrnice nicméně reagovala na skutečnost, že práva duševního vlastnictví jsou v oblasti internetu jen obtížně vymahatelná a stanovila oproti předchozí úpravě, na níž Doporučení Komise reagovalo, pro tato práva specifický režim, jehož cílem je zajistit efektivní vymáhání těchto práv v oblasti internetu. S ohledem na výlučná práva autora udílet svolení k užití svých děl s inherentně spojeným právem takové užití zakázat proto není logické, aby nositel práv v případě ex post oznámení o užití jeho díla, které si nepřeje, musel PSSOO věcně odůvodňovat oznámení protiprávního užití. Již z povahy věci totiž platí, že autor má výlučné právo udílet svolení k užití. Pokud poté někdo své užití argumentuje uplatněním výjimek, mělo by být na něm takové užití zdůvodnit a prokázat.

\subsubsection{ZVLÁŠTNÍ REŽIM ODPOVĚDNOSTI PRO NOVÉ POSKYTOVATELE -} START-UPY DLE ČL. 17 ODST. 6

Dle čl. 17 odst. 6 DSM směrnice podléhají noví PSSOO za splnění daných podmínek mírnějšímu režimu odpovědnosti. Tento zvláštní režim tak náleží pro PSSOO, kteří působí v EU po dobu kratší 3 let a kteří mají roční obrat nižší než 10 milionů EUR.

Komise apeluje na členské státy, aby tyto podmínky ve vnitrostátní úpravě dodržely a měly na paměti, že „tento mírnější režim odpovědnosti má zohlednit zvláštní př́pad nových společností, které pracují s obsahem nahraným uživateli, aby vytvořily nové obchodní modely. “99

V případě ročního obratu se dle DSM směrnice postupuje podle doporučení Komise o definici mikropodniků, malých a středních podniků. ${ }^{100}$ Komi-

\footnotetext{
99 Pokyny, s. 17. Srov. též možnost specifických licenčních podmínek pro nové uživatele v oblasti online užití v čl. 16 odst. směrnice o KS.

${ }^{100}$ Doporučení Komise ze dne 6. května 2003 o definici mikropodniků, malých a středních podniků. In: EUR-Lex [právní informační systém]. Úřad pro publikace Evropské unie [cit. 25. 7. 2021]. Dostupné z: https://eur-lex.europa.eu/legal-content/CS/TXT/?uri=celex \%3A32003H0361.
} 
se zde vhodně připomíná též Uživatelskou příručku $\mathrm{k}$ definici malých a středních podniků vypracovanou Komisí, která poskytuje podrobnější pokyny např. $\mathrm{v}$ př́ípadě spojování s jinými podniky. ${ }^{101}$

Pokyny dále stručně opisují úpravu ve směrnici, tj. zmiňují dvoustupňový režim pro nové PSSOO v závislosti na počtu návštěvníků služby. Pokud totiž počet měsíčních jedinečných návštěvníků služby překročí 5 milionů, má daný PSSOO kromě povinnosti vynaložení veškerého úsilí k získání licence a odstranění obsahu na základě odůvodněného oznámení nositele práv též povinnost po tomto oznámení též zamezit jeho budoucímu nahrávání. Komise tak připomíná, že průměrný měsíční počet návštěvníků se určí na základě předchozího kalendářního roku, přičemž je třeba zohlednit návštěvníky ze všech členských států. ${ }^{102}$

Pokyny poté uvádějí, že i v prrípadě nových PSSOO je třeba dodržovat princip proporcionality ohledně naplnění podmínek vyloučení odpovědnosti dle čl. 17 DSM směrnice. Komise zde dokonce výslovně uvádí, že $\mathrm{u}$ veškerého úsilí $\mathrm{k}$ zamezení budoucího nahrání oznámených děl $\mathrm{v}$ případě nových PSSOO s více než 5 miliony jedinečných návštěvníků by se od nich mohlo „očekávat méně než od poskytovatelů služeb spadajicích pod čl. 17 odst. 4. Bylo by odpovídající, kdyby využívali méně komplexní a méně nákladná řešení. “103

Český návrh novely AZ a OZ tuto úpravu opět implementuje prakticky doslovně a nijak nevybočuje $\mathrm{z}$ textace DSM směrnice. ${ }^{104}$ Důvodová zpráva pak v souladu s recitálem 67 DSM směrnice uvádí, že

„zvláštní režim platný pro nové poskytovatele služeb s malým obratem a publikem by neměl být zneužíván. $O$ zneužití by šlo např. $v$ př́padě nově vytvořených služeb nebo služeb poskytovaných pod novým jménem, které by však provozoval již existujicí poskytovatel

\footnotetext{
${ }^{101}$ User guide to the SME Definition. ec.europa.eu [online]. Evropská Komise [cit. 25. 7. 2021]. Dostupné z: https://ec.europa.eu/regional_policy/sources/conferences/state-aid/sme/smedefinitionguide_en.pdf.

${ }^{102}$ Pokyny, s. 17-18.

${ }^{103}$ Tamtéž, s. 18.

${ }^{104}$ Viz § 48 návrhu novely AZ.
} 
služeb pro sdílení obsahu online, který tento mírnější režim již využívat nemůže. “105

V případě specifického volnějšího režimu, který dopadá na tzv. startupy, lze v obecné rovině vnímat jako legitimní, že tito noví poskytovatelé služeb mohou podléhat mírnější úpravě odpovědnosti. Je však třeba vnímat kriticky výslovné sdělení Komise, že u start-upů s více než 5 miliony jedinečnými návštěvníky měsíčně by se od nich mohlo očekávat využití méně komplexních řešení. Domnívám se, že právě požadavek na individuální posuzování naplnění podmínek vyloučení odpovědnosti může vést $\mathrm{k}$ tomu, že i platforma v postavení start-upu by měla uplatňovat nákladnější technická řešení, pokud již v počátcích svého fungování bude konkurovat velkým stávajícím platformám. ${ }^{106}$ Tedy výše uvedené sdělení Komise v Pokynech není př́liš vhodné. ${ }^{107}$

Komise dále uvádí, že v případě počtu návštěvníků je tř̌eba zohledňovat pouze návštěvníky z členských států EU. I tento aspekt je problematický, nebở přesný počet nemusí být vždy snadné určit - uživatelé se např. mohou připojovat přes tzv. VPN připojení. Není též jasné, zda je tím myšlena faktická návštěva z členského státu (tedy zahrnující i občany třetích zemí), nebo zda jde o návštěvníka - státního příslušníka členského státu (tedy je třeba počítat i návštěvy ze zahraničních IP adres). Návod k výkladu poskytuje recitál 66 DSM směrnice, který mluví o ,jednotlivých návštěvnících $v$ Unii.“ Tedy zřejmě je směřováno $\mathrm{k}$ návštěvám $\mathrm{z}$ IP adres spojených

${ }^{105}$ Důvodová zpráva k návrhu novely AZ a OZ, s. 55.

${ }^{106}$ Tak např. služba Youtube, spuštěná v únoru r. 2005, měla již v červenci 2006 v průměru 100 mil. zhlédnutí videí denně. První pokusy o spuštění technologie rozpoznávání obsahu na této platformě Content ID probíhaly již od června 2007. Viz History of YouTube. wikipedia.org [online]. Wikipedia [cit. 28. 7. 2021]. Dostupné z: https://en.wikipedia.org/wiki/ History_of_YouTube, a Content ID (system). wikipedia.org [online]. Wikipedia [cit. 28.7. 2021]. Dostupné z: https://en.wikipedia.org/wiki/Content_ID_(system).

107 Zajímavostí je prezentace české společnosti Seznam.cz z jednání Stakeholders Dialogue, kde Seznam.cz uvedl: „The goal of this presentation is to show that obviously every OCSSP can do its part, even the smallest one. [...] Commission guidelines shall explicitly dictate a set of minimum requirements for smallest players. As it is obvious, even the smallest OCSSP can do its part without any super-expansive toys. “Viz Prezentace společnosti Seznam.cz ze 4. jednání Stakeholders Dialogue [online]. Evropská komise [cit. 28. 7. 2021]. Dostupné z: https://digital-strategy.ec.europa.eu/en/events/fourth-meeting-stakeholder-dialogue-article-17-directive-copyright-digital-single-market. 
s členskými státy EU a tedy tím byli myšleni i státní příslušníci třetích zemí. Pro nositele práv nicméně bude v některých případech obtížné určit, že daná platforma v postavení nového PSSOO již porušila podmínky vyloučení odpovědnosti dle čl. 17 DSM směrnice, když nebude vždy schopná zcela jednoznačně určit počet jedinečných návštěvníků platformy.

\subsubsection{ZÁRUKY PRO OPRÁVNĚNÉ UŽITÍ OBSAHU A MECHANISMY VYŘIZOVÁNÍ STÍŽNOSTÍ A ZJEDNÁVÁNÍ NÁPRAVY \\ DLE ČL. 17 ODST. 7 A 9}

Komise již v úvodu Pokynů uvádí zásadní sdělení, kterým dovozuje jistou vyšší „sílu“ čl. 17 odst. 7, 8 a 9 nad ostatními ustanoveními čl. 17 DSM směrnice:

„Ustanovení čl. 17 odst. 7, 8 a 9 jsou formulována jako povinnosti týkající se dosažení výsledku. Členské státy by proto měly ve svých prováděcích právních predpisech zajistit, aby tyto povinnosti měly prednost $v$ př́padě, že by byly $v$ rozporu $s$ ustanoveními uvedenými na jiném místě $v$ článku 17, a zejména $v$ čl. 17 odst. 4. “108

Kromě záruk pro oprávněné užití obsahu dle čl. 17 odst. 7 a mechanismů vyřizování stížností a zjednání nápravy dle čl. 17 odst. 9 jde i o zákaz obecné povinnosti dohledu dle čl. 17 odst. 8 .

Článek 17 odst. 7 a 9 je tudíž třeba chápat jako performativní pravidlo, jehož cílem je zajistit, že žádné opatření v rámci čl. 17 nesmí vést k nedostupnosti obsahu, který neporušuje autorské právo, a to ani v důsledku uplatnění jakékoli výjimky či omezení. Komise zmiňuje, že tyto povinnosti jsou obzvlášṫ zásadní pro uplatňování nejlepšího úsilí ve smyslu čl. 17 odst. 4. ${ }^{109}$

Pod oprávněné způsoby užití pak Komise řadí několik skupin užití - užití na základě výjimek a omezení; užití na základě licence dle čl. 17 odst. 2 nebo na základě licence uživatele platformy; a užití obsahu, na nějž se autorské právo nevztahuje (např. volná díla). ${ }^{110}$

\footnotetext{
108 Pokyny, s. 3.

109 Tamtéž, s. 18.

${ }^{110}$ Pokyny, s. 19.
} 
Komise se dále zabývá mandatorní povahou výjimek a omezení uvedených v čl. 17 odst. 7 DSM směrnice, tj. výjimkami pro účely citace, kritiky a recenze či užití pro účely karikatury, parodie nebo pastiše a uvádí, že „výjimky nebo omezení uvedené ve [informační směrnici] jsou dobrovolné povahy a jsou určeny pro všechny uživatele a v př́padě citace, kritiky a recenze se na ně vztahují zvláštní podmínky. Naproti tomu provedení konkrétních výjimek a omezení uvedených $v$ čl. 17 odst. 7 je pro členské státy povinné, vztahují se výlučně a pouze na online prostředí a na všechny uživatele při nahrávání a zpř́stupňování obsahu vytvořeného uživateli [PSSOO] a pro jejich uplatňování neexistují žádné další podmínky. “111

Komise především dospívá $\mathrm{k}$ tomu, že veškeré uvedené výjimky či omezení je třeba považovat za autonomní pojmy práva EU. ${ }^{112}$ Členské státy by pak měly do̊slednou implementací zajistit soulad s LZPEU a s judikaturou SDEU.

Ohledně uplatňování čl. 17 odst. 4 v souladu s čl. 17 odst. 7 a 9 Komise dovozuje, že kombinace povinností uvedených v odst. 7 a mechanismus stížností a náprav stanovený v odst. 9 vede $\mathrm{k}$ tomu, že „pro provedení a uplatňování čl. 17 odst. 7 by proto nepostačovalo obnovení oprávněného obsahu ex post podle čl. 17 odst. 9 poté, co byl odstraněn nebo $k$ němu byl znemožněn př̀istup. “ Komise k tomu uvádí, že stávající technologický vývoj zatím neumožňuje automatizované posuzování oprávněného užití, umožňuje pouze identifikaci obsahu, z čehož dospívá k tomu, že „pokud nahrávaný obsah odpovídá konkrétnímu souboru poskytnutému nositeli práv, mělo by být automatizované blokování, tj. zamezení nahrání pomocí technologie, v zásadě omezeno na nahrávaný obsah zjevně porušující autorské právo." Pokud o zjevné porušení práva nejde, měl by obsah být dostupný a podléhat ex post posouzení člověkem. Postup by tedy měl být odlišný u tzv. prima facie

\footnotetext{
111 Tamtéž, s. 19.

${ }^{112}$ Viz rozhodnutí Soudního dvora (velkého senátu) ze dne 3. 9. 2014. J. Deckmyn ad. proti H. Vandersteen ad. Věc C-201/13. Dostupné z: https://curia.europa.eu/juris/document/document.jsf?text $=$ \&docid $=157281$ \&pageIndex $=0 \&$ doclang $=$ CS\&mode $=1$ st $\&$ dir $=\&$ occ $=$ first \&part $=1 \& \operatorname{cid}=2708332$.
} 
porušení autorského práva a u ostatních možných porušení. ${ }^{113}$ Komise uvádí, že pokud nositel práv neposkytl platformě pokyny k zablokování, neměl by být daný obsah považován za zjevně porušující autorské právo. ${ }^{114}$

Komise dále detailně popisuje možná relevantní kritéria $\mathrm{k}$ posouzení zjevně protiprávního obsahu. Mưže jít např. o délku či velikost zjištěného obsahu, podíl zjištěného obsahu v poměru k celému nahrávanému obsahu či míra pozměnění díla. Pokud dojde ke shodě celých děl nebo jejich významných částí s nahrávaným obsahem, měl by být takový obsah běžně posouzen jako zjevně porušující právo. Pokud se bude shodovat jen zčásti, zvyšuje se pravděpodobnost tvưrčího pozměnění a tudíž i užití díla na základě jedné z výjimek, tudíž takový případ nebude zpravidla zjevným porušením práva. Stejně tak tomu má být v případě užití krátkých úryvků díla, které v kontextu užití mohou spadat pod výjimku pro citaci. Komise dodává, že mohou existovat i složitější případy, a tudíž „klíčem $k$ postupnému doladění uplatňování tohoto mechanismu je spolupráce mezi poskytovateli služeb a nositeli práv a zpětná vazba od uživatelio." ${ }^{115}$

Pokyny též uvádějí, že v případě obsahu, jehož nahrání by mohlo nositelům práv způsobit značnou újmu, je možné zajistit pro nositele práv předchozí označení takového obsahu (tzv. pre-flagging), u něhož by mohlo na základě zjištění automatizovaného nástroj rozpoznávání obsahu dojít rovnou též $\mathrm{k}$ ex ante přezkumu člověkem. Tak by tomu ovšem mělo být jen $\mathrm{v}$ případě časově citlivého obsahu (např. filmy před vydáním či sestřih nedávno vysílaného sportovního utkání). Komise nicméně dodává, že pokud PSSOO takovouto ex ante kontrolu člověkem zavede, měl by do režimu zahrnout i mechanismy ke zmírnění rizik zneužití. ${ }^{116}$

\footnotetext{
${ }^{113}$ Srov. rozhodnutí Soudního dvora (tř̌etího senátu) ze dne 3. 10. 2019. E. Glawischnig-Piesczek proti Facebook Ireland Limited. Věc C-18/18- Dostupné z: https://curia.europa.eu/juris/document/document.jsf?text $=\&$ docid $=218621 \&$ pageIndex $=0 \&$ doclang $=$ CS $\&$ mode $=$ lst\&dir $=$ \&occ $=$ first\&part $=1 \&$ cid $=2712267$.

114 Pokyny, s. 21-22.

115 Tamtéž, s. 22-23.

116 Tamtéž.
} 
V případě zablokování obsahu by o tomto měl být uživatel bezodkladně informován, aby mohl zablokování napadnout $\mathrm{v}$ rámci mechanismu stížností a náprav dle čl. 17 odst. 9 DSM směrnice.

Pokud obsah zjevně neporušuje autorské právo, měl by být dostupný, avšak PSSOO by měl informovat nositele práv - v případě vznesení námitky ze strany nositele práv by mělo dojít $\mathrm{k}$ ex post přezkumu člověkem a $\mathrm{k}$ rozhodnutí, zda bude obsah ponechán dostupný. Komise tudíž obecně dospívá $\mathrm{k}$ tomu, že během přezkumu člověkem má daný obsah zůstat online. $\mathrm{O}$ výsledku přezkumu by měl být uživatel i nositel práv ihned informováni. Uživatel poté může využít mimosoudního řešení sporu dle čl. 17 odst. 9 DSM směrnice. ${ }^{117}$

Důležitým praktickým závěrem je zmínka o tom, že „mechanismus popsaný $v$ těchto pokynech by neměl bránit možnému využití technologie pro vykazování užití povoleného obsahu a odměňování za užití tohoto obsahu podle smluvních podmínek, na kterých se nositelé práv a poskytovatelé služeb dohodnou. “118

Český AZ již ve stávající podobě obsahuje značnou část výjimek a omezení z autorského práva dle čl. 5 informační směrnice. Český návrh novely $\mathrm{AZ}$ a OZ tak této $\mathrm{v}$ oblasti pouze do $\S 38 \mathrm{~g}$ doplňuje chybějící výjimku pro tzv. pastiš. ${ }^{119}$ Český návrh tuto výjimku zavádí obecně, ne jen pro užití $\mathrm{v}$ režimu dle čl. 17 DSM směrnice. Důvodová zpráva $\mathrm{k}$ tomu uvádí, že pojem pastiše je třeba vnímat jako autonomní pojem práva EU. Rovněž tak je při využití této výjimky dodržet tzv. tř́krokový test ve smyslu § 29 odst. 1 $\mathrm{AZ}^{120}$

Mechanismus stížností a náprav dle čl. 17 odst. 9 DSM směrnice je v návrhu novely AZ uveden v $\S 51 \mathrm{AZ}$. V odst. 1 je obecně v souladu se směrni-

\footnotetext{
117 Tamtéž, s. 23-24.

118 Pokyny, s. 24.

119 „Slovník spisovného jazyka českého uvádí, že pastišem se rozumí „literární, hudební nebo výtvarné dílo napodobující techniku, styl jiného díla“. Pastiš jakožto zpưsob uměleckého vyjádření je $v$ současnosti často využíván uživateli služeb pro sdílení obsahu online, když při tvorbě vlastního obsahu používají styl nebo techniku (např. výtvarnou) jiných autorů a tyto své výtvory poté zpřistupňují veřejnosti prostřednictvím služby pro sdílení obsahu online (nahrají na úložiště pro sdílení obsahu).“ Důvodová zpráva k návrhu novely AZ a OZ, s. 45.

${ }^{120}$ Tamtéž. s. 46.
} 
cí uvedeno, že PSSOO je povinen zavést mechanismus stížností a náprav, který může využít uživatel služby v případě sporů týkajících se znemožnění přístupu k jím nahranému obsahu nebo k jeho odstranění. Odst. 2 uvádí, že $\mathrm{v}$ pokud v případě postupu dle odst. 1 trvá nositel práv na odstranění obsahu, musí svoji žádost řádně zdůvodnit. Důvodová zpráva k tomu uvádí, že „v př́padě, že i po obdržení stížnosti bude nositel práv trvat na zachování přijatého opatření (tj. znemožnění př́stupu $k$ obsahu nebo jeho odstranění), musí to rádně zdůvodnit. “" ${ }^{121}$ Odst. 3 nakonec uvádí, že stížnost dle odst. 1 musí být vyřízena bezodkladně. Posouzení stížnosti nesmí být „výhradně automatizované“. Důvodová zpráva k tomu uvádí:

„Stížnosti by měly být vyřizovány bez zbytečného odkladu a konečné posouzení by mělo být učiněno člověkem. Volba konkrétního postupu (mechanismu) vyřizování stížností je ponechána na poskytovateli služby, který tak má možnost zvolit takový postup, který bude vyhovovat (např.) typu obsahu a počtu nebo povaze obvyklých stížnosti. “122

Komise se $\mathrm{v}$ této oblasti pustila do poměrně komplexního a detailního návodu, jakým zpo̊sobem by zde PSSOO měl postupovat. Zásadní úvahou je odlišný postup vůči obsahu, který „zjevně porušuje autorské právo“, a vůči ostatnímu nahrávanému obsahu. Kritickým momentem je závěr, že obsah, u nějž nedal nositel práv PSSOO pokyn k zablokování, tj. neposkytl relevantní a nezbytné informace ve smyslu čl. 17 odst. 4 písm. b) DSM směrnice, nemůže být považován za zjevně porušující autorské právo. V kombinaci s úvahou, že pouze stejné či drobně technicky pozměněné kopie chráněných děl, u nichž jsou poskytnuty informaci nositelem práv, mohou být blokovány ex ante, je zřejmé že Komise hledala cestu, jak vybalancovat práva na ochranu duševního vlastnictví a práva na svobodu projevu či práva na informace.

Tuto snahu lze ocenit, avšak požadavek na označování obsahu, jehož dostupnost na platformě zpơsobí nositeli práv značnou újmu, v kombinaci s úvahou, že pouze obsah zjevně porušující autorské právo může podléhat

\footnotetext{
${ }^{121}$ Důvodová zpráva k návrhu novely AZ a OZ, s. 57.

122 Tamtéž.
} 
ex ante blokaci, povede $\mathrm{k}$ nadměrné potřebě mechanismu stížností náprav. Tím spíše se pak domnívám, že stanovení povinnosti pro nositele práv řádně odůvodňovat své žádosti $\mathrm{k}$ odstranění obsahu $\mathrm{v}$ rámci mechanismu stížností a náprav jen snižuje postavení nositelů práv a fakticky obrací důkazní břemeno oprávněného užití z uživatelů na nositele práv. Ačkoliv totiž lze chápat, že je třeba vyvážit právo na přístup $\mathrm{k}$ informacím a svobodu projevu a právo na ochranu duševního vlastnictví, je třeba konstatovat, že prve uvedená práva nutně nevyžadují pro své uplatnění užití děl a jiných předmětů ochrany chráněných autorským právem. Tudíž dle mého názoru bude v naprosté většině případů převažovat význam práva autora na udělení svolení či zákazu užití svého díla nad právem na svobodu informací či svobodu projevu. Tím spíše je na místě uvažovat nad blokací obsahu do vyřešení sporu o uplatnění příslušných výjimek či omezení z autorského práva, než nad ponecháním jeho dostupnosti a požadavku na autora, aby svoji stížnost proti užití obsahu řádně odůvodnil. Vhodnější a praktičtější variantou vyvažující práva autorů a uživatelů internetu by dle mého názoru mohla být situace, kdy obsah bude na platformě ponechán, ale do vyřešení sporu nebude moci generovat žádné př́ijmy z reklamy u daného nahraného obsahu. $\mathrm{V}$ takovém př́padě bude zachováno právo uživatelů a veřejnosti na svobodu projevu a informací a zároveň nebude docházet k obohacování platformy či jejích uživatelů na úkor nositele práv - tj. nedocházelo by $\mathrm{k}$ tzv. value gap, který byl hlavním důvodem vzniku nové úpravy. ${ }^{123}$

V době přijímání DSM směrnice zazníval často jako hlavní argument proti nové úpravě fakt, že uživatelé platforem často tvoří obsah za využití výjimek a omezení z autorského práva, že taková transformativní užití jsou ze své povahy uplatněním výjimek a omezení z autorského práva a jsou projevem svobody projevu či tvưrčí tvorby. ${ }^{124}$ Často opomíjenou skutečností nicméně je, že každé uplatnění výjimky či omezení z autorského práva pod-

\footnotetext{
${ }^{123}$ Viz např. Transfer of Value - How Article 17 levels the playing field. authorsocieties.eu [online]. GESAC [cit. 4. 8. 2021]. Dostupné z: https://authorsocieties.eu/policy/transfer-ofvalue/.

${ }^{124}$ Viz např. What is Article 13? The EU's divisive new copyright plan explained. wired.co.uk [online]. WIRED [cit. 4. 8. 2021]. Dostupné z: https://www.wired.co.uk/article/what-isarticle-13-article-11-european-directive-on-copyright-explained-meme-ban.
} 
léhá tzv. tříkrokovému testu. Na tento fakt upozorňuje i důvodová zpráva k návrhu novely AZ a OZ. ${ }^{125}$ Užít díla bez svolení nositele práv tak lze „pouze ve zvláštních př́padech stanovených zákonem a pouze tehdy, pokud takové užití díla není $v$ rozporu s běžným zpưsobem užití díla a ani jím nejsou nepřměřeně dotčeny oprávněné zájmy autora. “" ${ }^{\text {"26 }}$ Nepostačuje tudíž pouhé formální naplnění výjimky či omezení v textaci zákona. Obzvlášt v př́ípadě komerčních uživatelských profilů či v dnešní době populárních tzv. youtuberů je zřejmé, že tito uživatelé jsou při tvorbě obsahu značně motivováni vidinou zisku z tvorby a nahrávání obsahu na dané platformy a tudíž již mohou být nepřiměřeny dotčeny oprávněné zájmy autora užitého díla. Ačkoliv DSM směrnice nezavádí pass-through efekt na profesionální či komerční uživatele platformy, fakticky umožňuje, aby dohoda nositelů práv a PSSOO zohledňovala i takové uživatele platformy. I bez takové dohody však může komerční záměr a reálný finanční úspěch nahraného obsahu vést $\mathrm{k}$ porušení tř́krokového testu. I tento aspekt je argumentem pro to, aby povinnost prokázat oprávněné užití díla náležela uživateli, který obsah nahrál, nikoliv nositeli práv.

\subsubsection{TRANSPARENTNOST INFORMACÍ POSKYTOVANÝCH NOSITELŮM PRÁV}

DSM směrnice ve svém článku 17 odst. 8 stanovuje určitý standard transparentnosti PSSOO vůči nositelům práv. Ten se dle směrnice týká informací o užití nástrojů, které PSSOO využívá k zajištění nedostupnosti obsahu, k jehož užití nebylo poskytnuto svolení, a informací o užití obsahu, pokud byla mezi PSSOO a nositelem práv uzavřena licenční smlouva.

Komise v Pokynech nabádá členské státy, aby poskytovatelům služeb dodaly „údaje o tom, jaký druh informací mají poskytovat, sohledem na

\footnotetext{
${ }^{125}$ Důvodová zpráva k návrhu novely $\mathrm{AZ}$ a OZ, s. 46.

${ }^{126}$ Viz $§ 29$ odst. 1 AZ. Tř́ḱkrokový test je autorskoprávním standardem zavedeným jak evropským, tak mezinárodním právem, viz 7. GEIGER, Christophe, GERVAIS, Daniel J., SENFTLEBEN, Martin. The Three-Step-Test Revisited: How to Use the Test's Flexibility in National Copyright Law. [online] In: American University International Law Review, Vol. 29, Issue 3. s. 583-626. [cit. 4. 8. 2021]. Dostupné z: https://digitalcommons.wcl.american.edu/cgi/ viewcontent.cgi referer $=\&$ httpsredir $=1 \&$ article $=1816 \&$ context $=$ auilr .
} 
nutnost dodržení čl. 17 odst. 7, odst. 8 prvního pododstavce a odst. 9.“127 Komise tudíž apeluje na zajištění vhodné spolupráce, která zajistí uplatňování výjimek a omezení z autorského práva, nepovede $\mathrm{k}$ obecné povinnosti dohledu nad obsahem a umožní fungování mechanismu stížností a náprav.

$\mathrm{V}$ případě informací o uplatněných technologických nástrojích ze strany PSSOO Komise uvádí, že tyto informaci by mohly zahrnovat např. popis druhů technologií, popř. informace o poskytovateli technologií, pokud jím je třetí strana, průměrnou míru účinnosti nástrojů a změny těchto nástrojů či služeb. PSSOO nemusí být v poskytovaných informacích příliš konkrétní, aby případně neporušil obchodní tajemství či průmyslové vlastnictví. ${ }^{128}$

Pokud bylo poskytnuto svolení k užití, Komise dovozuje, že PSSOO by měl nositeli práv poskytnout informace o využívání jeho děl a o př́ijmech, které z toho PSSOO dosáhl. PSSOO však není povinen poskytovat individualizované a podrobné informace o každém díle - toto si nicméně může nositel práv s PSSOO dojednat odlišně. Komise nakonec zmiňuje, že PSSOO by měly používat dostupné osvědčené postupy a odvětvovými standardy pro poskytování informací, pokud jsou dostupné; v př́ípadě kolektivních správců pak platí konkrétnější požadavky stanovené čl. 17 směrnice o KS. ${ }^{129}$

Český návrh novely $\mathrm{AZ}$ a OZ danou úpravu přejal do navrhovaného $\S 50$, kdy uvádí, že PSSOO je povinen

„poskytnout autorovi na jeho žádost přměřené informace o postupech podle $\S 47$ a 48 a bylo-li takovému poskytovateli služby udèleno oprávnění $k$ výkonu práva na sdělování díla veřejnosti podle $\S 18$ odst. 2, je povinen poskytnout autorovi na jeho žádost informace o užití díla, na které se toto oprávnění vatahuje. “130

Důležitým doplněním v českém návrhu je možnost uplatnění těchto práv nejen ze strany nositele práv, ale též ze strany osoby, která smluvně či na základě zákona nabyla výhradní oprávnění $\mathrm{k}$ výkonu práva dílo užít. ${ }^{131}$ Půj-

\footnotetext{
${ }^{127}$ Pokyny, s. 26.

${ }^{128}$ Pokyny, s. 26-27.

129 Tamtéž, s. 27.

${ }^{130} \S 50$ odst. 1 písm. a) návrhu novely AZ.

${ }^{131} \S 50$ odst. 2 návrhu novely AZ.
} 
de tak často o nakladatele, kolektivní správce či např. o zaměstnavatele či objednatele.

V dané oblasti jsou Pokyny poměrně stručné a obecně vystihují záměr DSM směrnice. Zcela správný je odkaz na čl. 17 směrnice o KS, který je proveden i v § 98 odst. 2 a v § 98c AZ a který je v praxi již několik let uplatňován. ${ }^{132}$ Kriticky se lze pouze vymezit proti zmínce Komise v návaznosti na recitál 68 DSM směrnice o tom, že nositelé práv a PSSOO se mohou domluvit též na podrobnějším poskytování informací o užití jejich děl. Domnívám se, že vyjednávací pozice platformy je v tomto směru výrazně silnější než pozice nositele práv a DSM směrnice v tomto směru bohužel nositeli práv zcela nepomáhá. Skutečnou možnost tyto formáty korigovat či ovlivnit tak budou mít pouze kolektivní správci na základě směrnice o KS či významní nositelé práv ve smyslu $§ 95$ odst. 3 písm. c) AZ. Pozitivně je proto třeba vnímat doplnění v $\S 50$ odst. 2 návrhu novely AZ.

\section{ZÁVĚR}

Pokyny Komise k uplatňování čl. 17 DSM směrnice se snaží nabídnout cestu pro osoby dotčené novou úpravou. Je nicméně zřejmé, že Komise v jistém směru zachází až příliš daleko, když se snaží vyplňovat právní mezery textace DSM směrnice, což jí v daném kontextu zcela nepřísluší. Obzvlášt výmluvným příkladem je v tomto úvaha Komise nad subsumpcí práv na rozmnožování díla pod licence udělené ke sdělování, resp. zpřístupňování díla veřejnosti. Ačkoliv se lze ztotožnit s tím, že evropský zákonodárce v tomto ohledu zásadně pochybil, je vhodnou cestou spíše výklad Soudního dvora nebo novelizace směrnice. Právně nezávazné Pokyny tudíž vytvářejí značnou právní nejistotu a mohou ohrozit již poměrně zavedený systém licencování v oblasti hudby a audiovizuálního obsahu.

\footnotetext{
${ }^{132}$ Projevem je užívání standardizovaných formátů hlášení o užití děl typu CRD či DDEX, které navazují na standardizované kódy autorských děl a nositelů práv typu IPI kódu či ISWC kódu. K tomu viz např. snahy finského předsednictví EU z r. 2019 o studii a další kroky v oblasti tzv. Copyright infrastructure, Developing the Copyright Infrastructure - Stocktaking of work and progress under the Finnish Presidency 15016/19 ze dne 20. 12. 2019. consilium.europa.eu [online]. Rada Evropské unie [cit. 28. 7. 2021]. Dostupné z: https://data.consilium.europa.eu/doc/document/ST-15016-2019-INIT/en/pdf.
} 
Další nevhodné právní posouzení ze strany Komise je možné spatřit v závěru, že tzv. live-streaming nespadá do působnosti režimu čl. 17 DSM směrnice. Oblast live-streamingu je poměrně vrtkavou oblastí v licenční praxi a určitou nejistotu lze vypozorovat i v akademické sfére. ${ }^{133} \mathrm{I}$ zde se domnívám, že takové posouzení nepřísluší Komisi a nemělo být předmětem Pokynů, jak předpokládá čl. 17 odst. 10 DSM směrnice.

V jistém smyslu je pozitivem snaha Komise vybalancovat různé dotčené zájmy a především střet základních práv, pokud jde o blokování obsahu či užití na základě výjimek a omezení z autorského práva. Komplikovanost Pokynů v tomto směru je však dle mého názoru dalším důkazem toho, že režim čl. 17 DSM směrnice má za cíl především důsledné licencování obsahu. Tím spíše by dle mého názoru bylo vhodné licencování užití v režimu čl. 17 směrnice podřadit pod tzv. rozšířenou kolektivní správu. Kolektivní správci jsou totiž povinni udělovat licence uživatelům chráněných děl za rovných podmínek a takovou licenci mohou odmítnout jen ve výjimečných př́ípadech. Rovněž tak Pokyny zdůrazňují nepominutelnou roli kolektivních správců jako základních kontaktních míst pro uplatnění nejvyššího úsilí platforem k získání licence. Došlo by tak k tomu, že by většina užití podléhala licencování, čímž by byla snížena potřeba uplatňování specifických režimů dle čl. 17 odst. 4 písm. b) a c) či odst. 7 a 9 DSM směrnice. Zároveň by však bylo zachováno právo jednotlivých nositelů práv či nezávislých správců práv a dalších entit licencovat svá práva individuálně. Potřeba tzv. vyloučení účinků hromadných smluv $\mathrm{v}$ režimu rozšířené kolektivní správy ${ }^{134}$ by pak vedla $\mathrm{k}$ tomu, že by kolektivní správce disponoval seznamem nositelů práv, kteří si přejí svá práva licencovat individuálně. Takový seznam by následně mohl kolektivní správce poskytnout dané platformě, čímž by se značně zefektivnila praxe při uplatňování čl. 17 DSM směrnice.

Ačkoliv velká část členských států vyčkávala na vydání Pokynů, aby získala návod $\mathrm{k}$ implementaci, $\mathrm{s}$ mírnou dávkou ironie je třeba konstatovat, že je dobře, že Komise vydala Pokyny až tři dny před implementační lhůtou směrnice. Členské státy se tak bez vydaných Pokynů z opatrnosti povětši-

\footnotetext{
${ }^{133}$ Viz sub 50.

${ }^{134}$ Srov. § 97e odst. 2 AZ.
} 
nou držely textace směrnice a nezacházely do přílišných detailů. Tím se zvyšuje pravděpodobnost, že směrnice bude v celé EU implementována obdobně. Výklad ustanovení DSM směrnice Soudním dvorem EU by tak nemusel vést $k$ nutnosti rozsáhlých novelizací vnitrostátních autorskoprávních předpisů. Ačkoliv je na místě souhlasit s tím, že právní úprava v DSM směrnici je relativně vágní, je třeba brát v potaz, že čl. 17 DSM směrnice je fakticky regulací orientovanou na výsledek - jakákoliv kazuistická právní úprava v oblastech spojených s moderními technologiemi totiž bude vždy za jejich vývojem zaostávat. Tudíž je zpoždění vydání Pokynů dle mého názoru v jistém smyslu spíše vítané. Lze proto vnímat pozitivně, že český návrh novely $\mathrm{AZ}$ a $\mathrm{OZ}$, ačkoliv není prost chyb zákonodárce, je věrný textaci DSM směrnice a nijak zvláště z ní nevybočuje.

Bude velmi zajímavé sledovat, zda Soudní dvůr EU přiřkne Pokynům určitý závaznější status obdobně jako např. u průvodce Bernskou úmluvou z r. 1978, nebo zda bude s Pokyny naopak polemizovat a povede svůj výklad proti Pokynům.

\section{POUŽITÉ ZDROJE}

\subsection{MONOGRAFIE}

[1] POLČÁK, Radim a kol. Autorský zákon. Praktický komentář s judikaturou. 1. vyd. Praha: Leges, 2020, 864 s. ISBN 978-80-7502-391-9.

[2] TELEC, Ivo.; TŮMA, Pavel. Autorský zákon: Komentář. 2. vyd. Praha: C. H. Beck, 2019, 1295 s. ISBN 978-80-7400-748-4

\section{2. ČLÁNKY}

[3] HUSOVEC, Martin, QUINTAIS, J. P. How to license Article 17? Ex-ploring the Implementation Options for the New EU Rules on Content-Sharing Platforms. [online] 27 s. [cit. 11. 7. 2021]. Dostupné z: https://papers.ssrn.com/sol3/papers.cfm?abstract_id = 3463011 .

[4] NORDEMANN, Jan Bernd. Art. 17 DSMCD a Class of Its Own? How to Implement Art. 17 Into the Existing National Copyright Acts - Also a Comment on the Recent German Discussion Draft. [online] 23 s. Dostupné z: https://ssrn.com/abstract $=3649626$.

[5] SLIWKA, Rostislav. Poskytovatel služeb sdílení obsahu online dle směrnice (EU) 790/2019. Revue pro právo a technologie. [Online]. 2020, č. 21, s. 91-128. [cit. 2021-07-14]. Dostupné z: https://journals.muni.cz/revue/article/view/13228. 
[6] ROSATI, Eleonora. Does the duration of the storage matter? Live streaming providers as 'online content sharing service providers' under Directive 2019/790. [online] 8 s. [cit. 2. 8. 2021]. Dostupné z: https://papers.ssrn.com/sol3/papers.cfm?abstract_id = 3594793 .

[7] GEIGER, Christophe, GERVAIS, Daniel J., SENFTLEBEN, Martin. The Three-Step-Test Revisited: How to Use the Test's Flexibility in National Copyright Law. [online] In: American University International Law Review, Vol. 29, Issue 3. s. 583-626. [cit. 4. 8. 2021]. Dostupné z: https:// digitalcommons.wcl.american.edu/cgi/viewcontent.cgi?

referer $=\&$ httpsredir $=1 \&$ article $=1816 \&$ context $=$ auilr .

[8] MAZZIOTTI, Giuseppe. New Licensing Models for Online Music Services in the European Union: From Collective to Customized Management. [online]. 41 s. [cit. 10. 8. 2021]. Dostupné z: https://papers.ssrn.com/sol3/papers.cfm?abstract_id $=1814264$.

\subsection{JUDIKATURA}

[9] Rozhodnutí Soudního dvora (velkého senátu) ze dne 22. června 2021. Frank Peterson proti Google LLC a další a Elsevier Inc. proti Cyando AG. Spojené věci C-682/18 a C-683/18. Dostupné $\quad \mathrm{z}$ : $\quad$ https://curia.europa.eu/juris/document/document.jsf? text $=\&$ docid $=243241$ \&pageIndex $=0 \&$ doclang $=$ CS\&mode $=1$ st $\&$ dir $=\& o c c=$ first $\&$ part $=1 \& \mathrm{ci}$ $\mathrm{d}=592163$

[10] Rozhodnutí Soudního dvora (třetího senátu) ze dne 7. prosince 2006. SGAE proti Rafael Hoteles SA. Věc C-306/05. Dostupné z: https://curia.europa.eu/juris/document/document.jsf? text $=\&$ docid $=66355 \&$ pageIndex $=0 \&$ doclang $=$ CS\&mode $=1$ st \&dir $=\& o c c=$ first\&part $=1 \& \mathrm{cid}$ $=1214666$.

[11] Rozhodnutí Soudního dvora EU (pátého senátu) ze dne 2. dubna 2009. Hauptzollamt Bremen proti J. E. Tyson Parketthandel GmbH hanse j. Věc C-134/08. Dostupné z: https://curia.europa.eu/juris/document/document.jsf?text $=\&$ docid $=73634 \&$ pageIndex $=0 \&$ doclang $=$ CS\&mode $=1$ st \&dir $=\&$ occ $=$ first $\&$ part $=1 \&$ cid $=1222119$

[12] Rozhodnutí Soudního dvora (trretího senátu) ze dne 15. března 2012. SCF proti Marcu Del Corsovi. Věc C-135/10. Dostupné z: https://curia.europa.eu/juris/document/document.jsf?text $=\&$ docid $=120443 \&$ pageIndex $=0 \&$ doclang $=$ CS\&mode $=1$ st $\&$ dir $=\&$ occ $=$ first $\&$ part $=1 \& \operatorname{cid}=1232598$.

[13] Rozhodnutí Soudního dvora (velkého senátu) ze dne 3. 9. 2014. J. Deckmyn ad. proti H. Vandersteen ad. Věc C-201/13. Dostupné z: https://curia.europa.eu/juris/document/document.jsf?text $=\&$ docid $=157281$ \&pageIndex $=0 \&$ doclang $=$ CS\&mode $=1$ st $\&$ dir $=\&$ occ $=$ first $\&$ part $=1 \&$ cid $=2708332$.

[14] Rozhodnutí Soudního dvora EU (druhého senátu) ze dne 14. června 2017. Stichting Brein proti Ziggo BV, XS4ALL Internet BV. Věc C-610/15. Dostupné z: https://curia.europa.eu/juris $/$ document $/$ document.jsf?text $=\&$ docid $=191707 \&$ pageIndex $=0 \&$ doclang $=$ CS\&mode $=1$ st \&dir $=$ \&occ $=$ first \&part $=1 \&$ cid $=1539071$. 
[15] Rozhodnutí Soudního dvora (třetího senátu) ze dne 3. 10. 2019. E. Glawischnig-Piesczek proti Facebook Ireland Limited. Věc C-18/18- Dostupné z: https://curia.europa.eu/juris/document $/$ document.jsf?text $=\&$ docid $=218621$ \&pageIndex $=0 \&$ doclang $=$ CS\&mode $=1$ st $\&$ dir $=$ \&occ $=$ first\&part $=1 \&$ cid $=2712267$.

[16] Žaloba podaná dne 24. května 2019. Polská republika proti Evropskému parlamentu a Radě Evropské unie. Věc C-401/19. Dostupné z: https://curia.europa.eu/juris/document/document.jsf?text $=\&$ docid $=216823 \&$ pageIndex $=0 \&$ doclang $=$ CS\&mode $=$ req\&dir $=\&$ occ $=$ firs t\&part $=1 \&$ cid $=592943$.

[17] Stanovisko generálního advokáta Henrika Saugmandsgaarda Øe přednesené dne 15. července 2021. Polská republika proti Evropskému parlamentu a Radě Evropské unie. Věc C401/19. Dostupné z: https://curia.europa.eu/juris/document/document.jsf? text $=\&$ docid $=244201$ \&pageIndex $=0 \&$ doclang $=$ CS\&mode $=$ req \&dir $=\&$ occ $=$ first $\&$ part $=1 \& \mathrm{c}$ id $=1501914$

\subsection{INTERNETOVÉ ZDROJE}

[18] Copyright in the Digital Single Market Directive - Implementation. An EU Copyright Reform Resource. create.ac.uk [online]. CREATe [cit. 11. 7. 2021]. Dostupné z: https:// www.create.ac.uk/cdsm-implementation-resource-page/

[19] GESAC reacts to Article 17 Guidelines. authorsocieties.eu [online]. GESAC [cit. 11. 7. 2021]. Dostupné z: https://authorsocieties.eu/gesac-reacts-to-article-17-guidelines/

[20] The EU Commission's Refuses to Let Go of Filters. eff.org [online]. EFF [cit. 11. 7. 2021]. Dostupné z: https://www.eff.org/deeplinks/2021/06/eu-commissions-guidance-article-17-didnot-let-go-filters.

[21] JÜTTE, Bernd Justin, PRIORA, Giulia. A further step into a systematic distortion: The EC Guidance on Article 17 CDSM Directive further complicates copyright exceptions. coyprightblog.kluweriplaw.com [online]. Wolters Kluwer [cit. 11. 7. 2021]. Dostupné z: http://copyrightblog.kluweriplaw.com/2021/06/09/a-further-step-into-a-systematic-distortion-the-ec-guidance-on-article-17-cdsm-directive-further-complicates-copyright-exceptions/.

[22] Sněmovní tisk 1246, Novela z. - autorský zákon - EU. psp.cz [online]. Poslanecká sněmovna Parlamentu ČR [cit. 11. 7. 2021]. Dostupné z: https://www.psp.cz/sqw/historie.sqw? $\mathrm{o}=8 \& \mathrm{t}=1246$.

[23] Návrh zákona, kterým se mění zákon č. 121/2000 Sb., o právu autorském, o právech souvisejících s právem autorským a o změně některých zákonů (autorský zákon), ve znění pozdějších předpisů, a další související zákony. apps.odok.cz [online]. Elektronická knihovna připravované legislativy pro veřejnost [cit. 14. 7. 2021]. Dostupné z: https://apps.odok.cz/ veklep-history-version?pid = KORNBZVFDU6E

[24] ROSATI, Eleonora. Commission unveils Article 17 Guidance: 3 highlights. ipkitten.blogspot.com [online]. IPKat [cit. 11. 7. 2021]. Dostupné z: https://ipkitten.blogspot.com/ 2021/06/commission-unveils-article-17-guidance.html. 
[25] QUINTAIS, Joao Pedro. Commission's Guidance on Art. 17 CDSM Directive: the authorisation dimension. coyprightblog.kluweriplaw.com [online]. Wolters Kluwer [cit. 11. 7. 2021]. Dostupné z: http://copyrightblog.kluweriplaw.com/2021/06/10/commissions-guidance-onart-17-cdsm-directive-the-authorisation-dimension/.

[26] CISAC Global Collections Report 2020. cisac.org [online]. CISAC [cit. 14. 7. 2021]. Dostupné z: https://www.cisac.org/services/reports-and-research.

[27] Návrh zákona, kterým se mění zákon č. 121/2000 Sb., o právu autorském, o právech souvisejících s právem autorským a o změně některých zákonů (autorský zákon), ve znění pozdějších předpisů, a další související zákony. apps.odok.cz [online]. Elektronická knihovna připravované legislativy pro veřejnost [cit. 14. 7. 2021]. Dostupné z: https://apps.odok.cz/ veklep-history-version?pid $=$ KORNBV4JQPRG.

[28] GESAC reacts to Article 17 Guidelines. authorsocieties.eu [online]. GESAC [cit. 20. 7. 2021]. Dostupné z: https://authorsocieties.eu/gesac-reacts-to-article-17-guidelines/.

[29] Stakeholder dialogue on copyright. digital-strategy.ec.europa.eu [online]. Evropská komise [cit. 25. 7. 2021]. Dostupné z: https://digital-strategy.ec.europa.eu/en/policies/stakeholderdialogue-copyright.

[30] User guide to the SME Definition. ec.europa.eu [online]. Evropská Komise [cit. 25. 7. 2021]. Dostupné z: https://ec.europa.eu/regional_policy/sources/conferences/state-aid/sme/ smedefinitionguide_en.pdf.

[31] History of YouTube. wikipedia.org [online]. Wikipedia [cit. 28. 7. 2021]. Dostupné z: https://en.wikipedia.org/wiki/History_of_YouTube.

[32] Content ID (system). wikipedia.org [online]. Wikipedia [cit. 28. 7. 2021]. Dostupné z: https://en.wikipedia.org/wiki/Content_ID_(system).

[33] Developing the Copyright Infrastructure - Stocktaking of work and progress under the Finnish Presidency 15016/19 ze dne 20. 12. 2019. consilium.europa.eu [online]. Rada Evropské unie [cit. 28. 7. 2021]. Dostupné z: https://data.consilium.europa.eu/doc/document/ST15016-2019-INIT/en/pdf.

[34] ROSATI, Eleonora. The legal nature of Article 17 of the Copyright DSM Directive, the (lack of) freedom of Member States, and why the German implementation proposal is not compatible with EU law. ipkitten.blogspot.com [online]. IPKat [cit. 28. 7. 2021]. Dostupné z: https://ipkitten.blogspot.com/2020/08/the-legal-nature-of-article-17-of.html.

[35] Prezentace společnosti Seznam.cz ze 4. jednání Stakeholders Dialogue [online]. Evropská komise [cit. 28. 7. 2021]. Dostupné z: https://digital-strategy.ec.europa.eu/en/events/fourthmeeting-stakeholder-dialogue-article-17-directive-copyright-digital-single-market.

[36] Prezentace společnosti GESAC ze 4. jednání Stakeholders Dialogue [online]. Evropská komise [cit. 28. 7. 2021]. Dostupné z: https://digital-strategy.ec.europa.eu/en/events/fourthmeeting-stakeholder-dialogue-article-17-directive-copyright-digital-single-market.

[37] Transfer of Value - How Article 17 levels the playing field. authorsocieties.eu [online]. GESAC [cit. 4. 8. 2021]. Dostupné z: https://authorsocieties.eu/policy/transfer-of-value/. 
[38] What is Article 13? The EU's divisive new copyright plan explained. wired.co.uk [online]. WIRED [cit. 4. 8. 2021]. Dostupné z: https://www.wired.co.uk/article/what-is-article-13-article-11-european-directive-on-copyright-explained-meme-ban.

[39] Urheberrechts-Diensteanbieter-Gesetz - UrhDaG, § 1 odst. 4. Dostupné z: https:// www.bmjv.de/SharedDocs/Gesetzgebungsverfahren/Dokumente/UrhDaG_ENG.pdf?

$\_$blob $=$publicationFile\& $v=3$

\subsection{PRÁVNÍ PŘEDPISY}

\subsubsection{PRÁVNÍ PŘEDPISY ČR}

[40] Zákon č. 121/2000 Sb., o právu autorském, o právech souvisejí- cích s právem autorským a o změně některých zákonů, ve znění pozdějších předpisů. In: ASPI [online právní informační systém]. Wolters Kluwer [cit. 11. 7. 2021]. Dostupné z: https://www.aspi.cz/products/lawText/1/49278/1/2.

[41] Zákon č. 89/2012 Sb. , občanský zákoník, ve znění pozdějších předpisů. In: ASPI [online právní informační systém]. Wolters Kluwer [cit. 11. 7. 2021]. Dostupné z: https://www.aspi.cz/products/lawText/1/74907/1/2.

\subsubsection{PRÁVNÍ PŘEDPISY EU}

[42] Listina základních práv Evropské unie. In: EUR-Lex [právní informační systém]. Úřad pro publikace Evropské unie [cit. 11. 7. 2021]. Dostupné z: https://eur-lex.europa.eu/legalcontent/CS/ALL/?uri = CELEX:12012P/TXT.

[43] Směrnice Evropského parlamentu a Rady 2000/31/ES ze dne 8. června 2000 o některých právních aspektech služeb informační společnosti, zejména elektronického obchodu, na vnitřním trhu (směrnice o elektronickém obchodu). In: EUR-Lex [právní informační systém]. Úřad pro publikace Evropské unie [cit. 11. 7. 2021]. Dostupné z: https://eur-lex.europa.eu/ legal-content/CS/ALL/?uri = CELEX\%3A32000L0031.

[44] Směrnice Evropského parlamentu a Rady 2001/29/ES ze dne 22. května 2001 o harmonizaci určitých aspektů autorského práva a práv s ním souvisejících v informační společnosti. In: EUR-Lex [právní informační systém]. Úřad pro publikace Evropské unie [cit. 11. 7. 2021]. Dostupné z: https://eur-lex.europa.eu/legal-content/CS/TXT/?uri=CELEX:32001L0029

[45] Směrnice Evropského parlamentu a Rady 2014/26/EU ze dne 26. února 2014 o kolektivní správě autorského práva a práv s ním souvisejících a udělování licencí pro více území $\mathrm{k}$ právům $\mathrm{k}$ užití hudebních děl online na vnitřním trhu. In: EUR-Lex [právní inormační systém]. Úřad pro publikace Evropské unie [cit. 11. 7. 2021]. Dostupné z: https://eur-lex.europa.eu/legal-content/CS/TXT/HTML/?uri = CELEX:32014L0026\&from $=$ EN 
[46] Směrnice Evropského parlamentu a Rady (EU) 2019/790 ze dne 17. dubna 2019 o autorském právu a právech $s$ ním souvisejících na jednotném digitálním trhu a o změně směrnic 96/9/ES a 2001/29/ES. In: EUR-Lex [právní informační systém]. Úřad pro publikace Evropské unie [cit. 11. 7. 2021]. Dostupné z: https://eurlex.europa.eu/legal-content/EN-CS/TXT/? uri $=$ CELEX:32019L0790\&from $=$ cs.

[47] Návrh směrnice Evropského parlamentu a Rady o autorském právu na jednotném digitálním trhu - COM/2016/0593 final - 2016/0280 (COD). In: EUR-Lex [právní informační systém]. Úřad pro publikace Evropské unie [cit. 25. 7. 2021]. Dostupné z: https://eur-lex.europa.eu/legal-content/CS/ALL/?uri = CELEX\%3A52016PC0593

[48] Sdělení Komise Evropskému parlamentu a Radě COM(2021) 288 final ze dne 4. 6. 2021. Pokyny k článku 17 směrnice 2019/790 o autorském právu na jednotném digitálním trhu. Dostupné z: In: EUR-Lex [právní informační systém]. Úřad pro publikace Evropské unie [cit. 11. 7. 2021]. Dostupné z: https://eur-lex.europa.eu/legal-content/CS/TXT/HTML/?uri=CELEX:52021DC0288\&from $=$ EN.

[49] Doporučení Komise (EU) 2018/334 ze dne 1. března 2018 o opatřeních pro efektivní boj proti nezákonnému obsahu online. In: EUR-Lex [právní informační systém]. Úřad pro publikace Evropské unie [cit. 25. 7. 2021]. Dostupné z: https://eur-lex.europa.eu/legal-content/CS/ $\mathrm{TXT} / \mathrm{HTML} /$ ?uri $=$ CELEX:32018H0334\&from $=$ CS.

[50] Doporučení Komise ze dne 6. května 2003 o definici mikropodniků, malých a středních podniků. In: EUR-Lex [právní informační systém]. Úřad pro publikace Evropské unie [cit. 25. 7. 2021]. Dostupné z: https://eur-lex.europa.eu/legal-content/CS/TXT/?uri=celex $\% 3 \mathrm{~A} 32003 \mathrm{H} 0361$.

Toto dílo lze užít $v$ souladu s licenčními podmínkami Creative Commons BY-SA 4.0

International (http://creativecommons.org/licenses/by-sa/4.0/legalcode). 